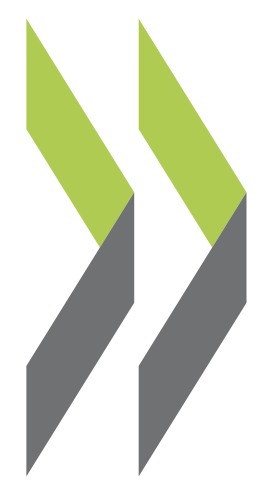

OECD Local Economic and Employment Development (LEED) Papers 2020/05

\title{
Museums and Local Development in Poland
}


OECD LOCAL ECONOMIC AND EMPLOYMENT DEVELOPMENT (LEED) PAPERS

\section{Museums and Local Development in Poland}

The OECD-ICOM Guide for Local Governments, Communities and Museums provides a framework for local and regional governments to assess and maximise the social and economic value of cultural heritage, and for museums to understand and strengthen their existing and potential linkages with the local economy and social fabric. This case study in Poland is based on nine museums of different size and ownership structure located in both large urban areas and rural municipalities. It explores opportunities for museums and local development in Poland along five dimensions: i) economic development, ii) urban design and community development, iii) culturally aware and creative societies, iv) inclusion, health and well-being, and v) mainstreaming the role of museums in local development.

JEL codes: $\mathrm{H} 41,010, \mathrm{Z18}$

Keywords: culture, museum, cultural heritage, local development, Poland 


\section{ABOUT THE OECD}

The OECD is a multi-disciplinary inter-governmental organisation of 36 member countries which engages in its work an increasing number of non-members from all regions of the world. The Organisation's core mission today is to help governments work together towards a stronger, cleaner, fairer global economy. Through its network of 250 specialised committees and working groups, the OECD provides a setting where governments compare policy experiences, seek answers to common problems, identify good practice, and co-ordinate domestic and international policies. More information available: www.oecd.org.

\section{ABOUT OECD LOCAL ECONOMIC AND EMPLOYMENT DEVELOPMENT (LEED) PAPERS}

The OECD Local Economic and Employment Development (LEED) Programme Papers present innovative ideas and practical examples on how to boost local development and job creation. A wide range of topics are addressed, such as employment and skills; entrepreneurship; the social economy and social innovation; culture; and local capacity building, among others. The series highlights in particular policies to support disadvantaged places and people, such as the low skilled, the unemployed, migrants, youth and seniors.

This paper is published under the responsibility of the Secretary-General of the OECD. The opinions expressed and arguments employed herein do not necessarily reflect the official views of OECD member countries or the European Union.

This document as well as any statistical data and map included herein are without prejudice to the status of or sovereignty over any territory, to the delimitation of international frontiers and boundaries and to the name of any territory, city or area.

Authorised for publication by Lamia Kamal-Chaoui, Director of the Centre for Entrepreneurship, SMEs, Regions and Cities, OECD.

This document was produced with the financial support of the European Union. Its contents are the sole responsibility of the authors and do not necessarily reflect the views of the European Union.

\section{Please cite this publication as:}

OECD (2020), "Museums and Local Development in Poland", OECD LEED Papers, 2020/03, OECD Publishing, Paris.

\section{(c) OECD 2020}

You can copy, download or print OECD content for your own use, and you can include excerpts from OECD publications, databases and multimedia products in your own documents, presentations, blogs, websites and teaching materials, provided that suitable acknowledgement of OECD as source and copyright owner is given. All requests for public or commercial use and translation rights should be submitted to rights@oecd.org. 


\section{Acknowledgements}

This project was led by Ekaterina Travkina, Coordinator, Culture, Creative Industries and Local Development of the OECD Centre for Entrepreneurship, SMEs, Regions and Cities. It was implemented in cooperation with the International Council of Museums (ICOM). The cooperation with ICOM was coordinated by Dorota Folga-Januszewska, Former President of ICOM Poland, and Afsin Altayli, Museums and Society Coordinator, ICOM Secretariat.

Country work was carried out by a research team led by Monika Murzyn-Kupisz (Jagiellonian University) including Jarosław Działek (Jagiellonian University), Katarzyna Gorczyca (Jagiellonian University) and Dominika Hołuj (Krakow University of Economics). The research team would like to thank all the museums and other museum stakeholders as well as local, county and regional governments in Poland who took part in interviews and questionnaires or provided valuable comments and insights, statistical, or qualitative data on the diverse activities and projects undertaken by museums. 


\section{Table of Contents}

Acknowledgements 3

Introduction $\quad 5$

$\begin{array}{lr}\text { Summary } & 9\end{array}$

1. Leverage the power of museums for economic development 13

2. Build on the role of museums for urban regeneration and community development 20

3. Catalyse culturally aware and creative societies 28

4. Promote museums as spaces of inclusion, health and well-being 34

5. Mainstream the role of museums in local development 40

$\begin{array}{ll}\text { References } & 48\end{array}$ 


\section{Introduction}

Museums and cultural heritage sites are powerful assets for local development. They can inspire creativity, boost cultural diversity, help regenerate local economies, attract visitors and bring revenues. There is also increasing evidence that they can contribute to social cohesion, civic engagement, health and well-being. For several decades now, cities and regions have been drawing on these assets to put in place heritageled actions as part of their wider economic development strategies. National, city and regional governments, the museum community, and other stakeholders are increasingly interested in these issues.

New ways to measure the impact of culture and museums on local development are being sought in order to effectively channel public and private funding. The debate is shifting from only demonstrating the tax revenues, visitor spending and jobs associated with a museum's economic activity to also capturing broader social and economic impacts. These impacts include community development through improved social capital, urban regeneration, place branding, inclusion, well-being, innovation and creativity.

To respond to this demand, in 2018 the OECD's Local Economic and Employment Development Programme (LEED) and the International Council of Museums (ICOM) partnered to develop a Guide for Local Governments, Communities and Museums to inform and support policy makers and the museum community. It includes potential actions in five areas:

1. Leverage the power of museums for economic development;

2. Build on the role of museums for urban design and community development;

3. Catalyse culturally aware and creative societies;

4. Promote museums as spaces of inclusion, health and well-being;

5. Mainstream the role of museums in local development.

\section{The case of Poland}

As part of the process to create the Guide, specific case studies have been undertaken in a number of countries, including Poland. This case study was carried out in 2018-19 with the support of the Polish Ministry of Investment and Economic Development and in co-operation with the National Committee ICOM Poland. The museums and localities included in the project were pre-selected by the OECD in cooperation with the project partners. The following museums and localities took part in the assessment:

1. Coal Mining Museum in Zabrze, an institution co-run by the municipality of Zabrze and the regional authorities of Silesia;

2. Historical Museum of the City of Krakow (HMCK), an institution of the City of Krakow;

3. Museum of Ancient Mazovian Metallurgy in Pruszków, an institution of the Municipality of Pruszków;

4. Museum of Folk Music Instruments in Szydłowiec, a regional institution supervised by the Mazovian region; 
5. Museum of King Jan III's Palace at Wilanów, Warsaw, a national cultural institution, supervised by the Ministry of Culture and National Heritage;

6. Museum of the Silesian Piasts in Brzeg, an institution co-run by the Ministry of Culture and National Heritage, Authorities of the Opole region and Authorities of Brzeg county;

7. The Tatra Museum in Zakopane, a regional institution supervised by the Małopolska region;

8. The Storyteller Museum - Museum of Folk Tales, Fairy Tales and Stories, a private sole proprietorship based in Konstancin Jeziorna; and

9. The Warsaw Rising Museum, a municipal institution of the Capital City of Warsaw. ${ }^{1}$

These institutions represent a variety of ownership, organisational and funding structures (owned by the state, region, or municipality, as well as public museums under mixed management and private museums $)^{2}$, are of different sizes and are located in different types of localities/municipalities. They range from very large institutions of international reputation based in major urban centres (Warsaw, Krakow), institutions with numerous branches (e.g. Zakopane), to smaller organisations located in more peripheral, smaller municipalities (Szydłów, Brzeg), including the specific case of a private museum run by one person in Konstancin Jeziorna.

Museums selected for analysis are in general active and rather innovative in their activities in the national context, or in the local setting in the case of smaller, more peripherally located museums. Some of them are among the most visited museums and tourist attractions in the country (Museum of King Jan III's Palace at Wilanów, Historical Museum of the City of Krakow, The Warsaw Rising Museum) or are located in major touristic centres (Warsaw, Krakow, Zakopane). Such museums have different challenges and problems (including investment pressures) than institutions in non-tourist, more peripheral or less economically developed municipalities (e.g. Szydłowiec, Brzeg). Though these museums are by no means representative of all museums in Poland, their experiences nonetheless shed light on the opportunities and challenges faced by museums more generally in Poland.

\footnotetext{
${ }^{1}$ For the remainder of the report, the museums will be referred to by their full names or by references to their location, e.g. Wilanów, Krakow, Zakopane. In the case where there is more than one museum institution in a given town or city, it is implied that the authors refer to the museum taking part in the OECD project.

${ }^{2}$ For more information and a general overview of the history and present day functioning of museums in Poland, their organisational structure and management, see the English language publications (among others) listed in the references of this paper.
} 


\section{Box 1. Overview of the museum sector in Poland}

In 2017, according to Statistics Poland, 949 museums and museum branches functioned in Poland. Broader estimates from a few years ago provided a much higher number of over one thousand. On the other hand, the State Register of Museums, which complies with stricter rules with respect to museum functioning standards, includes 128 institutions. They are responsible for over 10.5 million items in their collections and in 2017, were visited by 37.5 million persons, including 14.2 million free-of-charge visits and 5.5 million visits by school students. Apart from offering regular exhibitions, museums organised 3400 temporary exhibitions shown in the country and 164 exhibitions abroad. In 2017, over 84000 museum lessons were conducted at museums for over 1.8 million participants. In addition to regular visits and lessons, a number of diverse activities were organised by museums in Poland. These include readings, lectures and meetings (14 000 events a year), film screenings (23 200), concerts (2 800), competitions (on average one per museum per year), workshops (34 400) and outdoor events (2 600), the latter frequented by 3.1 million persons. Museums also conducted numerous research programmes and publishing activities.

As of 2017, almost four-fifths of Polish museums (79.3\%) belong to the public sector. These include 78 museums and museum branches of the central level authorities (mainly the so-called national cultural institutions) and 612 museums of territorial (local, county and regional) governments. Such a division of organisational and funding responsibilities is to a large extent the outcome of administrative reforms of 1999, whereby allotment of particular institutions to particular governance levels took place, along with decisions on the sharing of responsibilities for their management between different governance levels (the so-called co-run museums). Among private sector museums, 74 belonged to private persons, 51 to associations and foundations, 33 to religious organisations and churches, and only 7 were property of private companies.

At the state level, direct funding for museums is provided only for the national level institutions. There are also special funding schemes within the framework of the Ministry of Culture and National Heritage Programmes for which local, county and regional museums compete (e.g. so-called Minister's Programmes such as "Supporting museum activities" and "Museum collections"). EU funds (and in some cases Norwegian Financial Management- NFM funds) have been a major support for both the renovation of museum buildings and the undertaking new museum projects in Poland in recent years.

Museums constitute a relatively important position in the public budgets spent on culture (19\% of direct spending on culture and national heritage from the state budget, $12 \%$ of spending on culture and national heritage from the budgets of territorial governments). In absolute terms, both the number of museums and the amount of public spending on them is greater on the part of local and regional authorities. Public spending on museums from the state budget increased by $20 \%$ since 2015 , which noticeably exceeded the threshold of $1 \%$ of the budget. In 2017, PLN 635.4 million was spent on museums directly from the state budget and PLN 900 million by territorial governments. However, the share of spending on museums in the total public budget for culture, both at the national and territorial governance levels, is slightly declining. In addition, the spending of territorial governments is much more dispersed, as the number of institutions is high.

Similarly, although fast rising total visitor numbers on the national level are a reason for optimism, they have to be treated with caution due to two issues. First, the frequency of visits of Polish residents to museums has been rising at a slow pace in recent decades. In 2014, only $20 \%$ of residents of Poland visited a museum at least once a year, and just $1 \%$ more than four times a year (i.e. three times less than in Sweden, Denmark or the Netherlands). However, since 2014, the museum attendance rate has been growing by over 6 million visitors per year and reached over 20 million visitors in 2017. Secondly, large visitor numbers to major, large museums, either famous historic institutions and sites or new 
flagship institutions, mainly in major urban centres, are responsible for both the total visitor numbers and the stable increases in visit levels across Poland. Local, county and regional museums which are not major tourism attractions often cope with stagnating or declining visitor numbers. It should be noted that available statistics don't typically include smaller, especially private museums.

Source: Elaborated on the basis of: Statistics Poland, Culture in 2017 and 2018. See also: (Folga-Januszewska, 2011 [11]); (FolgaJanuszewska, 2012[2]]); (National Institute for Museums and Public Collections, 2018[3]]).

\section{Methodology}

Data collection for this case study included the following:

- Questionnaires completed by relevant partners (museums, local, county and regional authorities) in March and April 2018.

- Interviews with over 100 stakeholders conducted between April and June 2018, on average 11 per museum. This includes interviews with museum representatives (46); local, county and regional territorial governments (32); and external stakeholders including primary and secondary schools, non-governmental organisations, private firms, craftsmen, penitentiary institutions, cultural centres, a national park, etc. (24).

- Collection and analysis of statistical data (Museum Statistics Programme, museum reports to Statistics Poland- GUS and National Institute for Museums and Public Collections).

- Desk review of other relevant information in the academic literature, published sources and unpublished materials provided by particular museum institutions and local governments.

Two validation workshops were organised in June 2018 to present and discuss preliminary findings to relevant museums and other interested institutions and persons (in total almost 60 persons attended the two events). The first was held at the Museum of Jan IIl's Palace at Wilanów and the second at the headquarters of the Historical Museum of the City of Krakow. The workshops were moderated by Paulina Florjanowicz, Director of the Department of Cultural Heritage, Ministry of Culture and National Heritage; Joanna Staszak, Head of the Culture Department, Zakopane City Hall; Monika Wiejaczka, Deputy Director, Department of Culture, National Heritage and Promotion, Marshal's Office of the Malopolskie Region.

The preliminary results of the project were discussed at the annual meeting of ICOM Poland, at the OECD project meeting in the Louvre Museum in Paris, as well as presented by ICOM Poland Chair at the ICOM Annual Meetings (2018). The final conference presenting results and recommendations of the project took place at the Museum of Jan III's Palace at Wilanów in April 2019 and included an additional workshop on measures and recommendations to enhance the positive impact of museums, with the participation of representatives of OECD and ICOM. Lessons from the project were applied in the design of the new National Institute for Museums and Public Collections questionnaire on the functioning of museums in the socio-economic context and were distributed to a large sample of Polish museums in 2019 (this report does not cover the results of this questionnaire). 


\section{Summary}

This case study on museums and local development in Poland, undertaken in 2018-2019, focuses on nine museums of different size, located in different economic contexts and representing a variety of ownership, organisational and funding structures. It reviews the activities of these museums as well as municipal, county and regional authorities and other stakeholders in five areas important for local development:

1. Leverage the power of museums for economic development;

2. Build on the role of museums for urban design and community development;

3. Catalyse culturally aware and creative societies;

4. Promote museums as spaces of inclusion, health and well-being; and

5. Mainstream the role of museums in local development.

\section{Leverage the power of museums for local economic development}

Local governments recognise the role of museums in territorial branding and as a cornerstone of the visitor economy, however efforts often focus on the "star" museums. The potential of smaller museums, including their ability to attract a significant number of visitors and offer a complex visitor package, remains untapped in many places. This is often the case in municipalities "in the shadow of" larger metropolitan centres, where local authorities often consider that local residents and tourists will be more likely to make use of metropolitan downtown attractions. Moreover, regional authorities promote museums (through their specialised regional tourism boards) more than the local governments, regardless of which level of government owns the museum.

To increase the number of museum visitors, more could be done to ensure a smooth relationship with the tourism sector as well as to improve transport linkages. The relationship of museums with the tourism sector is often one-sided, whereby museums provide the tourism sector with information to design various visitor packages, however in turn tourism data is not shared with museums. Museum involvement in improving the quality of tour guide services and heritage interpretation is growing in the context of mass tourism and the deregulation of tour guiding services. Such involvement could also be a chance to make these services accessible to the prospective beneficiaries of the national Accessibility Plus Programme (see further information in Section 1). Organisation of transport and parking lots is an important element in improving museum accessibility to visitors, however its organisation does not always address museums needs nor are museums consulted when transport connections and parking lots are designed. Finally, there is a need to evaluate the impact of pilot programmes introduced by a number of regional authorities to link discounts for museum entrance with regional railroads tickets.

Cooperation between museums and local economic actors could be enhanced. Local governments are rarely involved in fostering linkages between museums and economic stakeholders. Regional and local authorities invest in museum infrastructure to create spaces which could be used for the promotion and study of the collections by artisans, designers and other stakeholders. However they rarely support cooperation projects between museums, universities science parks, FabLabs (fabrication laboratories) and 
other innovation stakeholders. Many museums are not fully recognised as potentially valuable partners in discussions on local development nor regularly invited to relevant meetings or provided with information which would enable them to voice sound opinions. Larger museums in major cities with access to more financial and human resources participate in such activities more often. The role of museums as institutions inspiring or engaging in the production and sale of good quality, locally made items could be recognised to a greater extent. Their sale receipts benefit the museums as well as the local producers and could be offered some support by local, regional and national authorities. Long-term sponsorship and private patronage are rather occasional and overall not an important source of funding for various reasons, including a lack of minimal tax incentives motivating corporate sponsorship and private donations.

Attention needs to be paid to the protection of intellectual and other property rights (IPR) of museums. Thus far, IPR protection has not been regarded as important for most Polish museums. Initiatives could be undertaken on the national level to raise museum awareness and knowledge on the issue.

\section{Build on the role of museums for urban regeneration and community development}

Collaboration for sustainable urban design and regeneration could be strengthened. Museums are rarely given a role to play when it comes to the discussions on urban planning and design, and there is no provision for legal recognition of this role of museums in this area. Only to a small extent may municipal museums be recognised as planning partners by municipal authorities, in particular when they are at the core of urban regeneration and tourism development programmes. Museums increasingly recognise the importance of outdoor spaces for exhibition, economic and social activity as well as leisure activities. Special government programmes could be introduced to assist museums in the renovation and adaptation of additional spaces to serve various economic and community purposes. At the same time, rising pressure for museum grounds to function as important public recreation areas is an increasing problem in areas where there is a tourist or residential construction boom. Such pressure occurs often without taking into account the necessary restrictions and limitations of uses for historic park grounds or the immediate vicinity of historic buildings.

Museums are active in building social capital in their localities but progress can be made, with the support of local and regional governments, in further diversifying museum cooperation with schools and the community and increasing volunteering. An increasingly important role for museums is that of building social capital within the local community. Polish museums often function as main meeting points and partners for non-profit organisations and local actors engaged in activities linked with heritage protection, conservation and promotion as well as for local development and quality of life. Community engagement through participatory practices is increasingly visible. It is developed by museums in cooperation with external stakeholders and is often very fruitful, even if of non-formal character such as participatory exhibitions, crowdsourcing (of knowledge, artefacts for exhibitions) and crowdfunding. Local government support to such activities is varied across Poland. Opportunities for building social capital in museums could be enhanced by the development of additional visitor services such as playgrounds, cafes and restaurants or conference and meeting rooms. These museum functions are usually foreseen in all new investment projects in new buildings and adapting existing structures to museum needs.

Support to volunteering is another important way to enhance linkages with local community. A broader museum volunteering campaign would be needed in Poland to attract volunteers from different age groups (including seniors) and address the needs for more training and organisational support on the legal and practical aspects of volunteering.

Museums' long-term cooperation with schools (beyond the standard education offer) is diverse and growing, including co-organisation of artistic competitions, gardening programmes, participatory 
exhibitions, co-organisation of counselling and summer camps. Such forms of cooperation between museums and educational institutions would merit more direct public support at the local and central government level.

Caution is required when merging some cultural services within an umbrella of one larger municipal institution (e.g. municipal cultural centres comprising of a library, a cultural centre and a museum). This kind of merger seems advisable in smaller communities as effective cost and resources sharing. However, in practice it often leads to the marginalisation and limiting of museum functions within such structures.

\section{Catalyse culturally aware and diverse societies}

The current legal framework does not explicitly recognise museums as educational or vocational institutions. This might make it hard for museums to develop activities in this sphere, beyond the usual offer for children and youth. Lack of such recognition also means that museums are not able to tap into additional special public funding for educational and professional training or provide certificates, unless they team up with partners who represent the educational sector (e.g. co-organisation of programmes with vocational schools or with universities).

In addition, the fact that school programmes do not explicitly foresee the visiting of museums weakens the potential educational and creative impact of museums. School visits to museums are not a rule but depend on the willingness of particular schools and teachers. In this framework, museum visiting is easier to integrate into school activities for lower education levels (with a more flexible teaching programme) than for higher levels.

There is a growing awareness of the need for a very careful introduction of multimedia and the limitations of multimedia exhibitions. Museums try to strike a balance between showing original objects and satisfying visitors' curiosity by providing electronic multimedia panels or copies of original objects. While larger museums have been able to develop comprehensive information tools, smaller/specialist museums might in turn cooperate with national and regional level institutions to create more comprehensive virtual tools.

\section{Museums as places for inclusion, health and well-being}

Museums are rarely explicitly recognised in municipal or regional development strategies as institutions which could contribute to social inclusion, health and well-being. Territorial governments usually do acknowledge that cultural institutions might play an important role in this domain but do not undertake specific activities to support museum involvement in such issues. Involvement of social care, employment and prison institutions in cooperation with museums is thus usually the matter of individual initiatives and is dependent on physical proximity to particular museum institutions. There are no special programmes that provide museums with information on socio-economic and health-related issues in a given location. Sharing of costs between museums and other institutions linked with social care and social inclusion cannot in practice be supported by local governments as spending of museums is a part of a different chapter of the public budget than spending on social care. There are also difficulties to support non-municipal institutions in the case of museums managed at the regional or state level.

Museums are increasingly involved in improving accessibility and developing programmes to address social exclusion, but this engagement is dependent on individual initiatives of museum employees and the management. The only area of broad explicit public support is the physical accessibility of museum buildings and sites (e.g. some investments linked with physical accessibility in museum buildings supported by the State Fund for the Rehabilitation for the Disabled - PFRON). Ongoing training of museum employees has been an important factor for the increase of museum offers adapted to 
the needs of the disabled with different requirements. The training is done in cooperation with or by specialised institutions, mainly non-governmental, as well as sometimes municipal organisations and special needs schools.

\section{Mainstream the role of museums in local development}

The local development potential of museums is increasingly recognised but cooperation between local and regional authorities and museums could be expanded. Museums are usually recognised as cultural amenities or a tourist attraction, and as such included in local and regional development strategies. Recently, they are also increasingly recognised as a part of the creative sector, especially in metropolitan cities and at the regional level, or as institutions potentially useful in the development of social capital. However, this recognition is rarely translated into the inclusion of museums as important actors in broader debates on local development. Cooperation between museums as well as local and regional authorities is often more a matter of individual initiatives rather than the outcome of effective legal frameworks. Moreover there are cases of unnecessary competition and duplication of cultural offers by local authorities. In general, more frequent and fruitful cooperation happens on the same governance level (between municipal museums and municipal authorities or regional museums and regional authorities). More intensive cooperation is undertaken at the regional level because regional authorities usually supervise several cultural institutions and are also more active in creating regional level cultural trails that often include museums.

Local financial and revenue regulations can incentivise the contribution of museums to local development. There have been no concrete motions undertaken by governing bodies at any level to measure the impacts of museums on tourism or residential attractiveness or to introduce local financial and revenue regulations that would incentivise museums financially for producing beneficial externalities. So far, Polish museums have not been penalised for economic efficiency (increased own earnings) by decreasing public financial contribution to their budget, though perhaps introduction of a certain legal safety mechanism with respect to this issue could be considered. The possibility of the participation of museums in the proceeds from the tourism tax could be explored following the redefinition and introduction of a new law on the tourism tax levied by local authorities. In places where the stay of tourists is mainly motivated by interesting monuments and museums, a significant share of such tax could be allocated to monument conservation and to museums (such a solution would however require development of efficient and transparent income sharing mechanisms). 


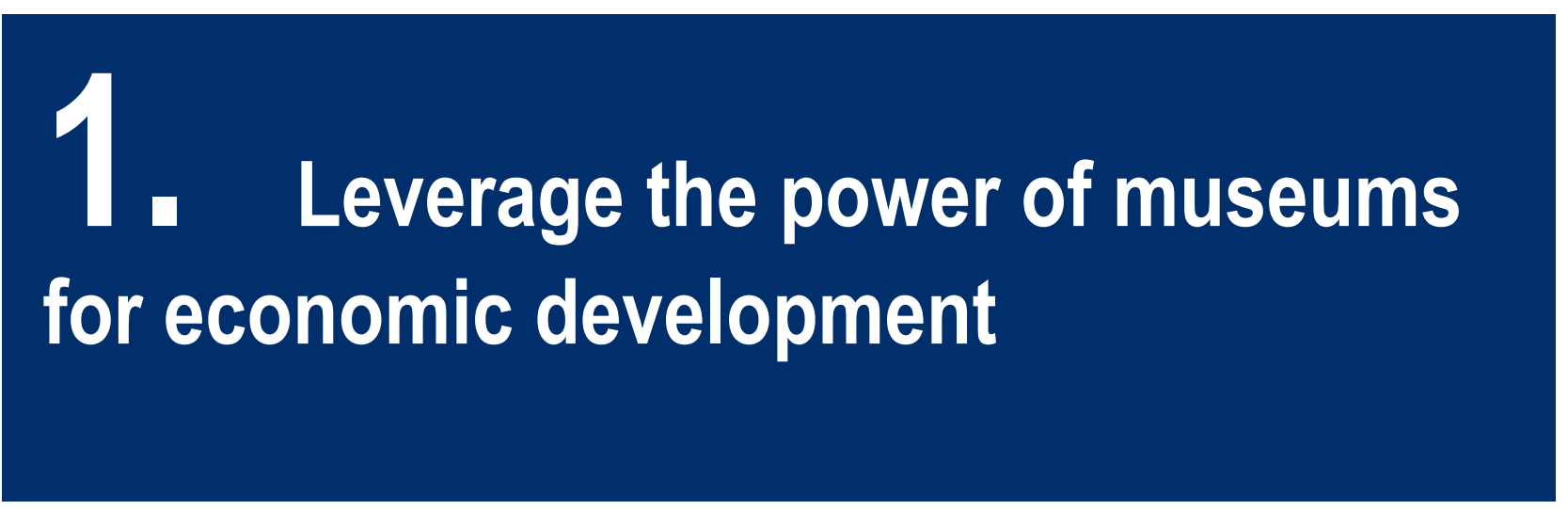

In addition to preserving and creating cultural value, museums contribute to local economic development through job creation and revenue generation related to the visitor economy. More long-term benefits can arise from partnerships between museums, local entrepreneurs, businesses, and higher education and research institutions that support the dissemination of new technologies and the creation of new products. Potential impacts include:

- New jobs and revenues through increased local attractiveness for tourists, talent and firms.

- Dissemination of new technologies, the creation of new goods and services, and support for creativity.

\section{Policy options for local governments}

In general, subnational authorities in Poland (local, county, regional) include museums in their promotion strategies and activities, recognising them as important (or potential) tourism attractions and contributors to the territorial branding. However, they do not get more deeply involved in stimulating museum cooperation with the private sector, creative industries, artists and craftsmen or the tourism sector. As the main actors for spatial planning investment in municipal transport infrastructure and public spaces, they influence the accessibility of museums, but do not always recognise museums as important partners or stakeholders who could voice valid concerns and opinions on such issues. Some attempts to coordinate different cultural offers as well as creating more complex tourism proposals (e.g. tourism trails) or combining train transport offers with museum tickets exist, mainly at the regional (voivodeship) level.

\section{Promoting museums locally, nationally and internationally}

In the Polish case, there are significant differences in how subnational governments work with museums depending on the formal ownership, financing and organisational relations between the two. In the case of municipal museums (i.e. owned and managed by local governments), local authorities tend to engage more intensively in promoting the museums as their own institutions, by printing leaflets, creating web pages and showcasing museums in international fairs and other events. This takes place, however, only when the museum is closely linked with the heritage brand of the area and is seen by the local authorities as an integral element of their vision for local development. For example, in the case of Zabrze, the Mining Museum is an integral part of the local authority's strategy to develop industrial tourism in the city as a means to help restructure the local economy. This strategy is further supported by the regional government, for example through the promotion of the Industrial Heritage Trail.

Large municipal museums or municipal museums which are flagship municipal cultural institutions and major tourism attractions (Warsaw Rising Museum, Historical Museum of the City of Krakow) are yet another case. They are the point of pride of local authorities and are considered strong enough to conduct 
promotion activities on their own without any particular help from local authorities (other than customary inclusion in general promotion materials). Such museums are seen more as a chance to promote the city thanks to the museum's popularity.

In the case of other museums with a less prominent profile, the involvement of local authorities in promoting museums is more limited, and consists mainly of including information on museum activities on municipal webpages and in municipal information periodicals and leaflets. This happens both in the case of municipal museums of a specialised nature (e.g. the case of the Museum of Ancient Mazovian Metallurgy in Pruszków appreciated but not particularly showcased by municipal authorities) as well as museums which are managed by higher authority levels (regional, state) or other entities (private). Local authorities include them in their promotion materials (both to tourists and to local audiences) but do not especially promote or showcase them (i.e. Zakopane, Brzeg, Wilanów, Konstancin Jeziorna), or even to a certain extent understand them as active players in the leisure, tourism and culture field. They usually also perceive broader promotion activities as unnecessary and not a sphere of their responsibility.

In some cases, the local government might not recognise smaller museums' potential as contributing to local branding. Museums are to a greater extent promoted by regional level authorities through their specialised regional tourism boards (e.g. the Mazovian Regional Tourism Organisation) and programmes, and usually regardless of museum ownership.

\section{Supporting the accessibility of museums for visitors and tourists}

Decisions on opening hours are usually left to museum directors and are dependent on financial considerations (in some cases municipal support is given for programmes outside of regular hours, e.g. in Krakow).

In recent years, a number of Polish regional authorities have initiated pilot projects to offer discounted museum entrance fees for visitors who use regional railroads to reach the museum (e.g. programmes in Silesian, Mazovia and Małopolska region). However, no detailed studies of such programmes' impact or popularity are available.

Museums are usually fully dependent on the organisation of transport and parking lots by the local municipality. In some cases, this issue is strongly recognised (Zabrze) or recognised at the lowest governance level (districts in Warsaw), though museum access is not always a top priority in designing transport and parking in urban areas from the broader city-level perspective (e.g. Zakopane, Pruszków).

\section{Promoting coordination between local cultural institutions to offer integrated programs that lengthen the stay of visitors}

Coordination of the programmes of museums and other cultural institutions usually happens through personal links and ties rather than through formal channels. Such coordination also takes place in practice as information is gathered in municipal bulletins and cultural information publications.

Although a question in other contexts, in Poland the fair sharing of revenue when museum tickets are sold to visitors by tourism offices has not been an issue to date. Museums sell their tickets directly or (increasingly) on-line. Only in rare cases have museums introduced limitations on group reservations by tour operators (e.g. in two popular museum branches in Krakow). Some municipalities have experimented with tourism passes and such passes have also been organised by private firms (e.g. in Zakopane), but so far none have achieved great success.

Local governments have no specific role in controlling the nature of information on museums provided by the private tourism sector. This issue has not been voiced as a concern in Poland. However, in practice, there is an issue of aggressive advertisement of private quasi-museum and non-museum establishments in tourism areas. Such institutions often do not fulfil the major functions expected of a museum or deliver 
services of rather poor quality despite promoting themselves as museums (e.g. many such private firms in Krakow).

Local governments do not control touristic brands or labels (this is done by accredited tourist service providers who meet certain quality standards). Local governments rarely create them - among analysed institutions, the only relevant example is Silesia and the Industrial Heritage Route. Among the analysed museums, only in the case of the museum of Zabrze did the local government encourage the museum to run its own tourism accommodation (a hostel) in order to create a more attractive tourism offer. The museum has also been encouraged to sell locally produced and designed goods in its museum store.

In some cases, local governments cooperate with museums on new initiatives to make the tourism season longer. The winter season "Garden of Lights" project in Wilanów is a good example of such an initiative. Initially intended as a leisure opportunity for local residents, it ultimately had great success as a tourism attraction. Other types of cooperation include the creation of heritage trails (e.g. in Zakopane); or the use of a museum's support to develop new heritage attractions which could lengthen tourist stays in the town (e.g. renovation of Town Hall interiors as a future attraction in Brzeg). In the case of private institutions (e.g. Konstancin), local governments might be unaware of the fact that a small institution attracts a significant number of visitors and offers a complex visitor package consisting of museum classes, workshops, a meal and a walk in the nearby nature area.

\section{Promoting partnerships between museums and economic actors}

Local and regional governments with direct responsibility for museums invest in museum infrastructure to create spaces for the study of the collections by artisans, designers and other stakeholders (e.g. in Zabrze). This often results in the creation of new goods inspired by the museum's collection. Sometimes museum souvenirs are used by the local government in its own promotion activities, again this is more likely if the museum is managed on the municipal level (e.g. souvenirs for official guests in Krakow).

\section{Policy options for museums}

\section{Strengthening links with the tourism sector}

Museums participate in some meetings and events of the tourism sector, especially in major tourism destinations. However, participation in such meetings is not always regarded as efficient, as most of the time, museums prefer to analyse their own observations and collect their own data on visitors, their needs and expectations as well as development trends due to the scarcity of data that is relevant to museums.

Similarly, they rarely cooperate with the tourism industry in the creation of new packages for tourists. Rather, they prepare their own new offers responding to promising trends, hoping that they will be noticed by tourists and the tourism industry. Strategies include teaming up with stronger public partners, more recognised in the tourism market (e.g. Tatra Museum with Tatra National Park). In other cases, they see no need for greater promotion to tourists (e.g. Warsaw Rising Museum).

The relationship of museums with the tourism sector tends to be one sided, wherein museums provide the latter with information to design various visitor packages but not the other way round. This information is used by the tourism sector to create new services and packages or more creatively interpret existing heritage resources. One example is the "Passage of Knowledge", Museum of King John III's Palace, which includes a dedicated webpage, where information is provided on diverse topics pertaining to the Old Poland period of the 17th and the 18th century, including the everyday life of King John and aristocratic 
families linked with the estate, leisure, hobbies, cuisine and dress, as well as the overall culture of the baroque and 19th century, with short entries capturing the attention of readers. ${ }^{3}$

Some museums in Poland cooperate with neighbouring museums to offer joint tickets as a way to create a more attractive tourism offer. One example is the joint ticket to two municipal museums: Historical Museum of the City of Krakow Schindler's Factory branch and the Museum of Modern Art. Another similar example is the joint ticket to a municipal and a state museum: Historical Museum of the City of Krakow Main Square underground branch and the National Museum Cloth Hall branch.

A growing trend in Poland is museums working to improve the quality of guided tours and heritage interpretation (e.g. Historical Museum of the City of Krakow), particularly in the context of mass tourism and the deregulation of tour guiding services. This could also be a chance to make these services accessible to the prospective beneficiaries of the national Accessibility Plus Programme. ${ }^{4}$ Museums may also organise and initiate study tours for tourism offices and tour guides from the broader area (e.g. region/county in the case of Tatra Museum). In their activities from time to time, museums enter barter agreements cooperating with firms from the tourism sector as well (e.g. advertisement in return for accommodation or catering at museum events such as exhibition openings).

Museums in Poland are also involved in the development of new brands for some areas and aspects of local or regional heritage in order to promote the unique tangible and intangible heritage of a given area. This is often done with involvement and in cooperation with local authorities. Examples of such activities include involvement in preparing applications for the Monument of History status as a national heritage label in Poland or leading efforts aimed at gaining official recognition of local or regional immaterial heritage, such as its inclusion on the national immaterial heritage list and potentially further on the UNESCO list of immaterial heritage (e.g. Zabrze, Krakow). Due to their success in the tourism market, some museums become tourism brands of a city, e.g. Schindler's Factory in the context of Krakow, Warsaw Rising Museum in the context of Warsaw.

\section{Deepening knowledge and information exchange with local stakeholders}

Museum directors and museum staff in Poland are usually rather well informed and aware of major issues and trends in local and regional development, especially challenges linked with socio-economic development at the local level (district of a larger city, municipality in the case of a small town). Larger museums in major cities with access to more financial and human resources participate in open meetings, round tables or forums on local development activities more often, but not all museums are equally recognised as potentially valuable partners in discussions on local development.

Museums engage in diverse forms of cooperation with non-governmental organisations on various educational, artistic and social inclusion programmes. In areas with significant investment pressures and increasing problems with balanced urban planning, museums might also become strategic partners of nongovernmental organisations focused on local quality of life (e.g. local associations of residents as in the case of Wilanów) or protection of cultural landscape and monuments (e.g. Society of Monument Admirers in Zakopane).

\footnotetext{
3 http://www.wilanow-palac.pl/pasaz?m=n

${ }^{4}$ Programme aimed at facilitating access to public spaces for people with special needs, through investment in infrastructure and awareness raising. See: https://www.funduszeeuropejskie.gov.pl/media/72628/Dostepnosc angielski.pdf
} 


\section{Partnering with economic development stakeholders}

In their day-to-day operations, museums cooperate with a variety of economic stakeholders. They include artisans and representatives of rare crafts, artists and firms in the creative sector, computer firms, various service providers as well as firms in the conservation and construction sector to name but a few. Museums are also involved in multidimensional cooperation with artists (e.g. Warsaw Rising Museum), including using museum collections as inspiration for the creative sector (e.g. Zakopane).

In recent years, many museums have developed or plan to develop this type of cooperation to a greater extent and in new directions. A new visible trend is museum involvement in imaginative historic reconstruction practices (e.g. pertaining to crafts, cuisine) and organising projects which encourage creative uses of museum collections (e.g. by fashion designers, jewellery, toy and board game designers) or which make it easier for artists to make practical use of the collections (e.g. access to archival material on music, clothing). Museums stress, among other issues, their growing role as references and training centres for rare crafts (e.g. making traditional music instruments, monument restoration and specialist conservation skills, textile production) as well as places of promotion and sale of new, innovative products - artworks and objects of contemporary design inspired by, and making references to, heritage.

The role of museums as institutions inspiring or engaging in the production and sale of good quality, locally made items could be recognised to a greater extent, as the sale receipts benefit the museums as well as the local producers. In addition, some museums become initiators and co-creators of cultural industry products - films, recordings, toy designs, etc. Museum interiors and outdoor spaces are also increasingly spaces of diverse artistic presentations and endeavours - concerts, theatre performances, dancing and poetry competitions, training sessions, festivals, film shows, etc.

Cooperation with artisans, artists and the creative sector is often indispensable and more intensive when more "active" ways of museum visiting are developed (e.g. workshops, courses on particular subjects or creative skills) or a more diverse programme offered (e.g. concerts, performances).

For these broader roles to be fulfilled by museums, however, more space is needed, and museum premises need to be adapted or renovated. Such activities also imply improving compliance with security and equipment requirements.

\section{Developing links with universities, incubators, science parks and other initiatives}

Museums in Poland have always been engaged in cooperation with scientific institutions drawing on the knowledge and skills of academic teachers and researchers. They have also been providing them with objects and archival material to study and with space and opportunities to communicate results of research endeavours. Today, museums are developing more diverse relationships with universities and research institutions, not only serving as reference centres but also as partners in innovative projects. This includes conducting joint research projects together with scientific and research institutions or testing and applying research results in their own activities (e.g. workshops and reconstruction activities, conservation activities) or publishing scientific journals. Art schools (of visual arts, music and design) might also be important partners of museums both as research institutions and as suppliers of creative skills. Another type of fruitful museum partners are institutions linked with environment protection (e.g. National Parks) whose goals to protect nature and cultural landscapes are in line with museums' aim to protect, disseminate and pass cultural heritage values to future generations (e.g. cooperation in Zakopane).

Museums can use the opportunity of working with economic actors to mobilise new sponsorships. However, in Poland long-term sponsorship and private patronage are rather incidental and overall not an important source of funding for museums. There are complex reasons behind this, ranging from the weakening tradition of private patronage in communist times, a relatively weak culture of corporate social responsibility, greater engagement of the private sector in supporting other activities (e.g. sports), and a lack of minimal tax incentives to motivate corporate sponsorship and private donations. 


\section{Managing intellectual property rights}

The protection of intellectual property rights has so far not been a major concern for most Polish museums. Among the museums in this study, only the Museum of King Jan III's Palace in Wilanów has undertaken major legal steps to both protect its intellectual property as well as to address its unlawful use. The small private Storyteller Museum is also aware of this issue, due to the uniqueness of the museum's offer. National initiatives could help to raise museum awareness and knowledge on the issue.

A very important issue in Poland, however, is the question of property rights, particularly ownership of items in museum care (e.g. long-term deposits) and real estate ownership. This is a very complex matter linked to World War II and its aftermath, including the nationalisation of private properties or the limiting of private ownership rights, the ad hoc distribution of some properties and lands to different public institutions after 1945, and the recent municipalisation and reprivatisation processes. This is a particularly important issue from the perspective of Wilanów and one of the branches of the Tatra Museum located in the village of Łopuszna.

\section{Opportunities for future action}

Based on the case study process and self-assessment framework, some possible opportunities for future action could include the following:

\section{Enhancing the role of (smaller and non-municipal) museums in territorial branding}

\section{Opportunities for regional governments}

- Strengthen, enable and increase the capacity of local governments to create, develop and manage their own touristic brands.

- Evaluate the impact of pilot train tickets and museum entrance schemes by regional authorities to see if it is advantageous in terms of increasing the accessibility of museums.

\section{Opportunities for local governments}

- When creating local touristic brands, focus on all types of museums (municipal, private, associative, church-affiliated, etc.) as well as small museums as much as the "star" museums, and support their cooperation with other culture centres.

- Research why efforts to increase the length of stay in the territory (such as through museum passes) have not been successful to date so programmes can be adapted accordingly.

\section{Strengthening the links between museums and the tourism sector}

\section{Opportunities for museums, regional and municipal tourism boards, and national level institutions}

- Consider returning to the obligation of licencing for tour guides or other forms of quality control, in particular in major urban centres. Major city and regional museums could be responsible for and entitled to conduct tour guide trainings, but would require additional financial support from the state budget for such activities.

- Facilitate information exchange with the tourism sector in a way that benefits both sides. Museums could develop their packages and offers building on the experiences of the tourism sector. Data from the tourism sector can help museums better place themselves in the tourism market. 
- Raise the awareness of the tourism sector (tour operators, offices, and guides) on the diversity of current offers by museum. One approach could be the organisation of an annual, national level Museum Fair.

\section{Putting in place favourable financial and fiscal frameworks for museum operations and diversification}

\section{Opportunities for local, regional and national government bodies}

- To the extent possible, provide medium to long-term predictable funding to museums (as opposed to the usual annual allocation of public budgets). This can help museums be able to engage strategically in local development processes and achieve meaningful impacts.

- Consider including museums in new legal provisions for the tourism tax levied by municipal authorities in Poland, recognising their possible participation in proceeds from this tax in municipalities where they are a major tourism attraction.

- Consult representatives of the museum sector in regards to changes in legal acts (e.g. bills, regulations) pertaining to museums (e.g. linked with spatial planning, law on public procurement).

\section{Opportunities for national level institutions (Museum Law)}

- Consider creating a legal "safety" mechanism with respect to museums retaining their own earnings and reinvesting them in statutory museum tasks. Consider legal provisions that could ensure that income generated by museums is not taken into account in the allotment of annual funding by managing bodies to avoid the possibility of "penalising" museums for economic efficiency.

- Consider ensuring on-going compulsory indexation of public museum budgets based on the inflation rate and growth in the size of museum collections, real estate managed and floor space. Develop a relevant indexation algorithm.

- Review whether current tax incentives for private donors and corporate sponsors encourage them sufficiently to provide support to museums.

- Strengthen public-private partnership as recently recommended to culture institutions. 


\section{Build on the role of museums for}

urban regeneration and community

development

Museums are places that contribute to both the physical and social design of many cities. Their renovation or construction can stimulate urban regeneration and bring new life into areas losing their social dynamism and traditional economic base. Museums appear to be places where social capital can be built between people of different communities when many traditional meeting places are disappearing. Potential outcomes could be:

- International branding and increased territorial attractiveness.

- Economic diversification, new jobs and revenues through the development of cultural and creative quarters.

- Better quality of life.

- Higher levels of social capital.

\section{Policy options for local governments}

\section{Considering the museum as a driver for sustainable urban design}

In discussions on urban planning and design, museums are rarely given a particular role to play beyond giving opinions and recommendations on strategic and planning documents, in particular pertaining to areas in the vicinity of museum buildings and sites, monument protection, as well as tourism infrastructure, municipal greenery and transport infrastructure, in some cases. The level of engagement depends on the nature of a museum's relationship with local government. This includes whether the museum has good institutional links with relevant authorities (i.e. institutional social capital), although these links can be fragile and prone to political fluctuations, as well as dependent on the ownership arrangements.

In the case of museums not owned by local governments, they are usually not treated as close partners but rather general participants in consultations without any special recognition or privileges (i.e. as any other type of organisation or firm). In this case, museums may provide formal comments, but do not participate in their detailed elaboration or final decision making on planning solutions.

Municipal museums may be recognised as planning partners by municipal authorities to a greater extent, in particular when they are considered an important aspect of urban regeneration and tourism development programmes envisaged by the local government. For example, in Zabrze, the museum is an integral partner in municipal urban regeneration programmes both in terms of the social aspects of regeneration and conservation and adaptation of historic industrial heritage sites. In Krakow, municipal museums play a role in the regeneration of the post-industrial area of Zabłocie. 
Museums are often located on attractive green grounds or nearby historic parks (e.g. Wilanów, Szydłowiec, Brzeg, Pruszków). Accessibility to museums and spatial links between museums and their vicinity are, however, not always fully taken into account in municipal urban planning.

A potential new area of cooperation between museums and local governments is the development of special local cultural landscape protection measures. Such measures are foreseen as a possibility under the Polish monument protection law and decided on by municipal councils. Their preparation usually requires significant specialist background information, and activities linked with explaining and promoting the idea, including providing the general public with arguments for stricter landscape protection measures (i.e. Cultural Park status). Polish local governments often draw on museums' help and expert knowledge as well as to some extent on their status as open and safe place for discussions for communities. For example, museums in Krakow and in Zakopane have been very actively involved in consultations, providing scientific knowledge and opinions on the guidelines of the Old Town Cultural Park in Krakow and the Krupówki Cultural Park in Zakopane.

In smaller towns, investments by higher levels of government (e.g. construction of new museum buildings) can be chances to introduce new, imaginative, and good quality architectural designs into their urban spaces, with support, encouragement or even in-kind land input of the local authorities (e.g. Szydłowiec).

An increasing problem in areas where there is a tourism or residential construction boom is rising pressure on museum grounds to function as main public recreation areas. Although museums increasingly recognise their role in provision of attractive outdoor spaces, it is problematic for this to be treated as an obligation or replacement of local government duties to provide such spaces in non-museum areas.

Another approach to involving museums in sustainable urban development can be seen in Krakow, where the municipality has been promoting more environmentally friendly transport, including in the museum where an increasing share of museum cars are to be electric. Other examples in Krakow include encouraging municipal employees, including municipal museum employees, to use public transport or bike to work instead of taking a car, and promoting and implementing sustainable heating and energy efficiency programmes in municipal museum institutions or giving grants to public institutions including museums.

\section{Making museums part of the regional/local "brand", highlighting their contributions to development and creativity}

Museums can function as important "trademarks" for some places, and local authorities are well aware of this fact. Local and regional authorities may cooperate with museums in the applications for, or development of, distinct local, regional, national or even international brands (e.g. UNESCO World Heritage or UNESCO immaterial heritage status; Monument of History status, development of a major regional heritage route such as the Industrial Heritage Route in Silesia or Trail of Wooden Architecture in Małopolska). This is more frequent in cases where municipal authorities are fully bought in to the added value of a particular brand or in the case of heritage trails developed by regional authorities. Local authorities also cooperate with museums or support them in the development of major cultural festivals (e.g. Zakopane) or flagship exhibitions. However, in some cases, local governments do not see the potential of museums to contribute to local branding, particularly in small municipalities in the shadow of larger metropolitan centres with broader cultural offerings.

\section{Mobilising the museum as a public place for building social capital}

Local and county level authorities usually recognise the role of museums as a meeting place. For example, they frequently serve as a place for prestigious local events (e.g. for local educational and cultural institutions, local city councils, welcoming official municipal guests, etc.); events and celebrations attended by large numbers of people (especially outdoor events); as well as other local events and celebrations (e.g. local festivals, "Days" of a given town or quarter, high school graduations, anniversary concerts, 
meetings and conferences of local deputies). They might also recognise museums' role in defining local identity and the need to make the local population familiar with them, for example by providing additional funding to ensure local school children can visit the museum (e.g. in Wilanów).

Different governance levels may approach the functions of a given museum differently (e.g. the local government in Pruszków sees the museum mainly as a small, local community space, while regional authorities see it as a potential tourism attraction). In some cases, the local/regional authority is well aware of and underlines the social capital function of museums. Municipal authorities support the well-known museum projects and events for local communities in the museum in Krakow. Małopolska regional authorities encourage the Zakopane museum to organise imaginative workshops and events for the local visitors. These supports are often provided regardless of the organisational level of governance (e.g. "the Culture Voucher" programme). Such supports can help museums balance their local functions for particular local communities and the tourism function. For example, in the Krakow museum, there is a clear differentiation of the scope and character of activities between different museum branches.

Local governments can also facilitate event organisation by developing corresponding urban services. In some cities, the development of the general public transport network benefits museums (e.g. Krakow). In many cases, however, improving access to museums is not a top priority of local authorities (e.g. problems with the organisation of parking lots in Pruszków, Zakopane, and Warsaw; signage, paving of roads and sidewalks, lack of local transport within a community in Konstancin Jeziorna).

Although some local governments in Poland contribute to the direct organisation of activities such as permanent creative artistic centres for amateurs within museums' structures, this has not been the case for the museums included in this study. If creative activities and courses provided by museums are supported by municipal authorities, it is rather within the framework of summer or winter holiday activities for local children. Artistic residences in museums have so far not been an activity of local governments in the municipalities in this study, though some of them expressed interest in this idea.

Museums (regardless of their organisational structure) often cooperate with local cultural centres and municipal libraries by sharing resources or co-organising events, many linked with the direct creative involvement of local residents (e.g. joint exhibitions, painting sessions, music or theatre activities, creative writing, etc.). However, caution is needed when merging some cultural services within an umbrella of one larger municipal institution (e.g. the Municipal Cultural Centre which includes a library, a cultural centre and a museum). In smaller communities, this can be an effective means to share costs and resources, but can also result in the marginalisation and limiting of museum functions within such a structure.

\section{Action options for museums}

\section{Treating the museum as a core feature in urban design}

On the one hand, museums in Poland are increasingly aware of and recognise their broader role within the urban fabric in terms of design and provision of attractive public spaces as well as spatial links with surrounding areas. This aspect is usually included in their plans for conservation and renovation of museum premises (e.g. Zakopane). Some of them initiate discussions on the re-use of abandoned or underused spaces (e.g. the Podgórze branch of the Historical Museum of the City of Krakow has initiated discussions on the possibilities to use abandoned space underneath the new railroad junction in PodgórzeZabłocie). Others have initiated projects to temporarily use spaces near the museum as leisure grounds in districts where due to fast development and dense construction, no green grounds are available to local residents and employees (e.g. small leisure area initiative of the Warsaw Rising Museum). Yet others organise activities outside museum interiors, making use of both green spaces managed by the museum and the nearby park areas (e.g. Pruszków). More and more museums take the opportunity (either on their own or with other partners including municipal authorities) to carry out some of their activities outdoors in 
urban space (e.g. museum urban walks, outdoor exhibitions of selected objects or board exhibitions in Zakopane, Krakow, and Warsaw).

On the other hand, as already mentioned, museums' formal role in urban planning is usually limited to giving inputs or comments, without any special privileges, or providing historic background information. In rare cases, larger museum institutions initiate discussions on local spatial development and challenges on their own, in particular in areas undergoing changes to the built environment linked with private, residential and commercial investments. For example, the King Jan IIl's Palace Museum in Wilanów has elaborated an innovative, comprehensive Museum Master Plan as a strategic document for the institution. This plan is also as a departure point for urban planning in the district, in particular in the vicinity of museum grounds, in the absence of up-to-date municipal planning documents. Particularly in towns and cities facing significant development pressures (major cities, well-known tourism destinations), museums may act as a reference point for proper, high quality conservation works in historic buildings, especially structures with unique, local architectural features (e.g. Zakopane), setting good examples for private investors.

However, museums are often limited in how they can impact the aesthetics and functions of their immediate surroundings (squares, streets, gardens, parks) due to different ownership arrangements between museum buildings and neighbouring spaces. For example, the museum in Brzeg is not the manager of a potentially attractive, but presently not accessible castle garden and has no influence on decisions related to the construction of a new hotel building next door. The museum in Szydłowiec uses some rooms in the Szydłowiec castle but is not responsible for its surroundings on the picturesque castle island. The museum headquarters in Zakopane are next to the main street of Zakopane (Krupówki) but to date, the local authority has not taken any particular actions to highlight the presence of the museum and other public institutions near the town's main pedestrian axis.

Many Polish museums are in historic buildings with significant conservation restrictions, have not been renovated for many decades or are only partly renovated, as well as being managed by different bodies (not only the museum). These factors limit the flexible use of spaces and physical access of certain visitor groups (e.g. the disabled). Museums are aware of this problem and when possible, in particular when constructing new buildings or renovating existing buildings, try to improve accessibility (e.g. planned conservation and adaptation works in the palace buildings and manor farm area in Wilanów; investments in Zakopane museum buildings; investments in several branches of the Krakow museum; new museum building in Szydłowiec). Such projects typically also aim to allow for the flexible use of selected internal spaces. For example, Krakow museum interiors are available to external stakeholders for different purposes such as educational activities, meetings and discussions, lectures, film screenings, book promotions, and local community meetings. Similarly in Szydłowiec and Zakopane, the current construction activities aim to make the museum interiors available to the local community, creators, and students for meetings, educational activities, and workshops, among other activities. The Zakopane museum has also started to renovate external places around some of its branches to allow open access and use by the general public (i.e. visitors to museum grounds who do not visit museum interiors). In some cases, the very nature of the museum makes its space very flexible. For example, due to scarcity of space in the small private building used by the museum in Konstancin Jeziorna, its main room is by definition used for different purposes in very imaginative ways, including by bringing in and removing necessary furniture.

Some museums have an active role in public spaces, including in other towns or regions. The private museum from Konstancin Jeziorna is an excellent example. As "visiting" this museum in practice means participating in creative performance - interpretation of heritage by its owner - the museum is very mobile. It conducts museum lessons, presentations and workshops wherever invited, often including outdoor activities both in its own municipality (e.g. in the park in Konstancin Jeziorna) and others. 


\section{Making the museum a driver of a creative district}

The idea to make a museum a driver for the development of a cultural or creative district has been voiced by some municipalities in relation to some museum investment projects. However, this idea is usually not fully implemented in practice (e.g. in Krakow - Zabłocie).

Among museums included in this study, there is a general agreement about the importance and value of museum collections as inspiration for contemporary artists. Museums are usually happy to provide information on, and access to, their collections for artists, artisans and designers. As already mentioned, many museums engage in cooperation with traditional craftsmen, who often practice disappearing crafts as well as with designers inspired by traditional forms and artistic details. Relevant associations of artists and artisans or guild organisations are also frequent museum partners. It is however (for organisational and financial reasons as well as due to formal limitations) beyond the scope of museum activities to provide direct support to artists or firms in the creative sector, other than consultations on project ideas, access to collections or working on the concept of and selling artisanal and design products in the museum shop. A museum's particular profile determines the type of artisans and artists it cooperates with most frequently. For example, the Zabrze museum attracts artists and artisans inspired by industrial objects and sites or working with specific materials such as coal. In Pruszków, collaboration extends to artisans inspired by Ancient Times, whereas Wilanów works with craftsman whose practice is linked with manors and palaces in the Early Modern Times. In the case of Zakopane, this includes artists, designers and objects referring to local vernacular traditions as well as early 20th century fashions. In Szydłowiec, cooperation relates to the themes linked with folk music and folk music instruments. For the Warsaw Rising Museum, artistic and artisanal activities are inspired by the history of World War II.

Due to its profile, organisational and financial possibilities, as well as available room for expansion (buildings and land for adaptation), one museum in the study has explicit plans to initiate a cluster of creative and artistic activities. It plans to encourage artisans and artists to produce, display and sell artisanal and artistic products as well as teach traditional craft techniques, utilising the historic palace manor farm (grange) nearby Wilanów palace.

An issue which would require broader consideration and clarification legally at the national level is how museums could be encouraged and legally authorised to start such activities, including functioning as formal training and education centres for rare crafts. The question of such limitations is not an issue for private institutions, although they may require public support to successfully enter the commercial market. For example, in the case of the museum in Konstancin Jeziorna, the owner has many interesting ideas for production and sales of objects (toys, boxes, construction blocks, poof ottomans) but limited capacities to effectively market them.

\section{Making the museum a contributor to rural/urban development}

Museums in rural areas often face specific challenges. Resources are often difficult to mobilise, human resources are not easily available and opening hours are usually seasonal and limited. Rural museums, especially in areas without a major tourist site, may need to rely even more upon pooling of back-office activities, organisation of common exhibitions and the support of volunteers. They can also benefit from new technologies and the creation of networks with larger museums in neighbouring cities or internationally.

Polish museums often function as key references, meeting points and partners for associations and local actors engaged in activities linked with heritage protection, conservation and promotion as well as associations for local development and quality of life (e.g. in Zakopane, Wilanów, Zabrze and Krakow). A particularly interesting initiative of this type is the Heritage Council in Zakopane.

Larger institutions in major urban centres (Warsaw, Krakow) have access to a wider pool of potential volunteers (not only teenagers but increasingly also senior citizens and other age groups), and are better 
prepared to use volunteers effectively. They have either already established (Warsaw Rising Museum) or plan to establish (Wilanów, Krakow) special Volunteer Centres. Smaller museums might find it much harder to enter into formal volunteering agreements and seem to be in need of more training and organisational support on the legal and practical aspects of volunteering. While cooperation with volunteers supports the functioning of many museums in Poland (e.g. Warsaw Rising Museum), a broader museum volunteering campaign could help further develop museum volunteering and attract volunteers from different age groups (including seniors), and provide museums with more training and organisational support on the legal and practical aspects of volunteering.

Museums in Poland are also increasingly engaging with national and international networks of museums. They are working most closely with other museums with similar types of collections, locations or focus (e.g. mining museums, mountain museums, museums in historic residences).

Due to legal and organisational constraints, the pooling of inputs and resources with neighbouring museums is not always possible (e.g. if two museums are owned and supervised by different actors). Some municipalities in Poland have started to use collective purchases to optimise costs (e.g. energy or water supply to municipal institutions, insurance). Museums can benefit from these activities provided that they are part of the municipality. On a day-to-day basis, particularly in regards to specific projects, museums share resources with neighbouring institutions, most often public institutions, for example lending each other equipment, using partners' spaces and grounds, making use of knowledge and skills of partner institutions, or sharing resources by sharing the same site (e.g. Szydłowiec). The scope and effectiveness of such cooperation depends on the resources available to each institution, as well as the personal relationships between the staff.

\section{Making the museum a lever of community life}

In recent decades, museums have become important actors in educating the general public about the historic multi-ethnic character of Polish lands both within contemporary and historic borders. These issues are relevant for general civic education and to promote awareness of local history, including addressing the complexity of local heritages and issues linked with their transmission. Likewise, there are also examples of incorporating the heritage of more recently arrived populations into the overall cultural narrative. For example, in Brzeg, both the museum and the local authorities are planning to organise a special exhibition on the history and culture of families forced to migrate from the former Eastern Borderlands of Poland after the end of WWII.

All of the museums in the study cooperate with a great number of local actors. They include kindergartens, primary and secondary schools, social care institutions, community groups and associations including heritage protection associations and foundations for local development, other cultural institutions, third age universities ${ }^{5}$, dioceses, parishes and other religious organisations, historic re-enactment groups, and local craftsmen and artists. They organise programmes and activities for schools, as well as for families and other age groups (e.g. seniors are increasingly considered an important visitor group). Museums also pay increasing attention to the comfort of different visitor groups (e.g. providing places for feeding and changing diapers to accommodate families with small children).

The character of the museum collection and the specificity of an area influences how it cooperates with its communities. For example, the Warsaw Rising Museum attracts war veterans and their associations as well as scouting organisations. Another example is the museum in Zabrze as a partner to miners' communities and organisations, including through its newly planned branch which will serve as a community centre for the local, historic mining community. Other examples include the museum in Szydłowiec, which cooperates with folk music instruments makers; the museum in Krakow and its

\footnotetext{
${ }^{5}$ The University of the Third Age is an international movement whose aims are the education of mainly retired members of the community.
} 
relationship with traditional Christmas crib makers; the museum in Zakopane and its links with musicians and fans of regional music and costumes; the museum in Brzeg and its links with associations of persons with roots in the historic Polish Borderlands (today within Ukraine and Belarus); the museum in Konstancin Jeziorna and its work with storytellers; and finally the museum in Wilanów and its links with associations and persons engaging in historic reconstruction activities. Cooperation with many institutions and groups is long term and allows for the development of ongoing ties with individuals. For example, school children who first participate in cooperation between the school and the museum may later become volunteers in the museum.

A noticeable trend is the effort of museums to engage with different forms of artistic expression to interpret their collections, making them more meaningful and interesting to visitors, and to use museum spaces in new ways. This pertains to museums' own programmes (e.g. workshops, artistic events), broader initiatives (e.g. multidisciplinary festivals) and providing or renting space to other artistic institutions and groups (e.g. drama groups, music ensembles, poetry associations, dance instructors, traditional craft makers).

Another important emergent sphere of museum links with local communities and community organisations is the participatory practices applied by the museum in cooperation with external stakeholders. These include participatory exhibitions, crowdsourcing (of knowledge, artefacts for exhibitions) and crowdfunding, and are often very fruitful, even if informal.

The museums in the study are also engaging in diverse forms of long-term cooperation with local schools beyond the simple provision of the standard museum offer (tours, lessons, workshops). Such activities include the co-organisation of artistic competitions, gardening programmes, participatory exhibitions, and co-organisation of counselling and summer camps, to mention but a few.

\section{Opportunities for future action}

Based on the case study process and self-assessment framework, some possible opportunities for future action could include the following:

\section{Partnering for sustainable urban design and regeneration}

\section{Opportunities for local governments}

- Recognise museums as key players in deciding the planning, use and the limitations of the museum grounds, and give them a decisive role alongside the local authorities in determining the cultural component of those public spaces.

- Explicitly involve museums in discussions related to the design and utilisation of ancillary infrastructure in their vicinity such as parking lots, signage, paving of roads and sidewalks, local transport, etc.

- Educate municipal employees and deputies on the impact of municipal investments on accessibility to museums.

- Foster greater recognition of museums as useful and knowledgeable planning partners as well as institutions which can provide knowledge related to the conservation of historic buildings and sites.

- Increase recognition of the impact of municipal strategic and spatial planning on the functioning of museums and of the need for sensitive planning in the vicinity of museums and heritage sites, taking into account historic and present spatial links as well as environmental and aesthetic considerations, regardless of ownership relations between a particular museum and a particular governance level. 


\section{Opportunities for museums}

- Seek to act in accordance with ICOM Milano 2016 Resolution: The Responsibility of Museums Towards Landscape 6 : "Museums have a particular responsibility towards the landscape that surrounds them, urban or rural. This implies a dual duty: on the one hand, the management and upkeep of heritage in a sustainable development perspective for the territory; on the other, attention given to images and representations that identify and connote the landscape itself."

\section{Enhancing museums' role in building social capital}

\section{Opportunities for local and regional governments}

- Create incentives and funding schemes to:

- Encourage partnerships between museums and non-governmental organisations in the development of museum projects (schemes that incentivise museums to engage in such cooperation).

- Encourage museums to engage in participatory practices and projects (e.g. participatory exhibitions, crowdsourcing of knowledge, artefacts for exhibitions, etc.)

- Support the development of various residences (artistic, research, curatorial, etc.) in museums as a means for imaginative use of collections and creating new links with local communities.

\section{Creating a more balanced offer for tourists and the local community}

\section{Opportunities for local authorities}

- Recognise the specificity of museum grounds as leisure areas with particular conservation and usage limitations that should not act as substitutes for municipally-managed parks and playgrounds.

\section{Opportunities for museums}

- Maintain a strategic balance between the use of museums for tourist attractions and as a place for the community.

- Develop additional visitor services in museums such as playgrounds, cafes and restaurants or conference and meeting rooms that act as spaces for social interaction for local visitors.

\section{Developing creative clusters/districts in cooperation with museums}

\section{Opportunities for local and national governments}

- Consider providing support (financial resources, physical infrastructure) to museums to create clusters of cultural activities and increase cooperation with other actors in order to develop creative districts. Museums could be encouraged and legally authorised to start such activities, including functioning as formal training and education centres for rare crafts.

\section{Opportunities for museums}

- Develop a programme of cultural offerings and engage in cooperation with other actors and the third sector to create clusters of cultural and cross-sectoral activities (including rare crafts).

\footnotetext{
6 The Responsibility of Museums towards Landscape, http://icom.museum/wp-content/uploads/2018/07//COMsResolutions 2016 Eng.pdf.
} 


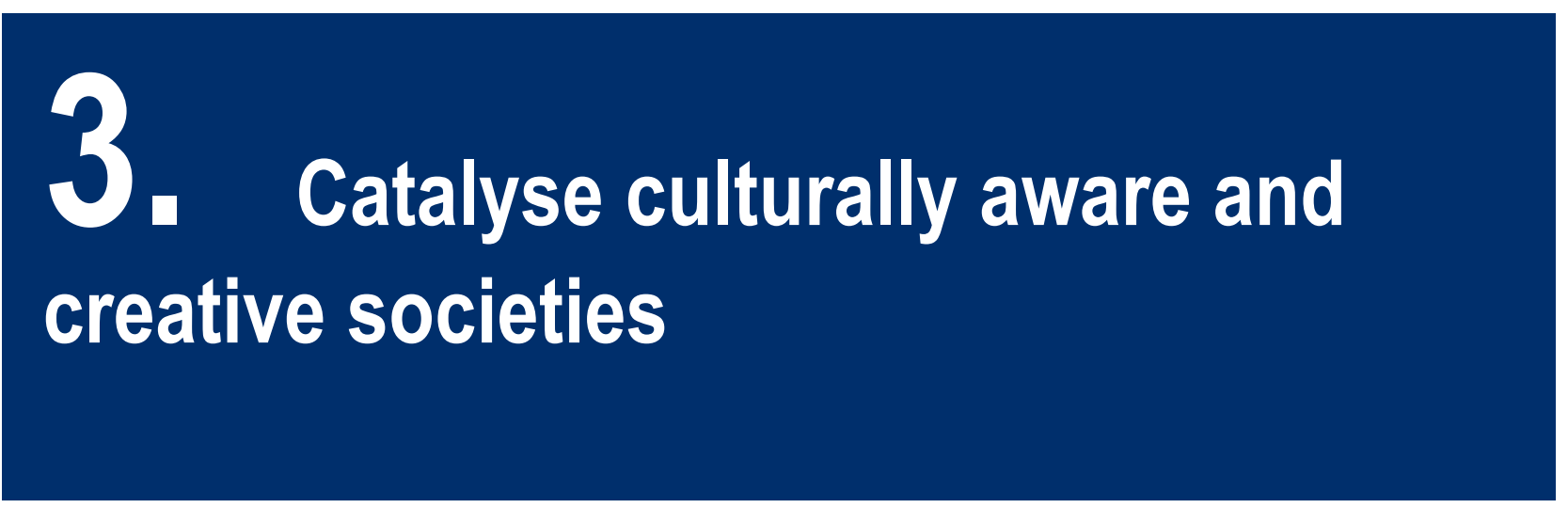

Museums have mainly been created to increase cultural awareness and education. With time, this objective has become more complex to also encompass training and life-long learning, and not only for native populations but also immigrants and other marginalised communities. A museum's mission is also to promote reflection and self-awareness by providing opportunities to audiences to learn more about their environment and themselves through their collections. They can change the way people think about many past and contemporary issues and can challenge misperceptions and rigid modes of thinking. By displaying an inventory of past creativity, museums help promote an understanding of why and how things have been created. In that sense, they may distil a broader culture of creativity.

Potential outcomes include:

- Knowledge development and upskilling.

- Increased levels of self-confidence.

- More culturally aware and open communities.

- Diffusion of creativity.

\section{Policy options for local governments}

\section{Recognising museums' role in cultural and educational development}

The degree to which local governments recognise museums as drivers of cultural development varies, with much depending on the attitudes and knowledge of particular local authorities, including local mayors, deputies and municipal employees. Museums work to raise awareness and develop a stable working relationship with particular local government officials or deputies by inviting them to the museum, including them on the Museum Advisory Board, regularly providing information on on-going museum activities, etc. However, efforts spent on "educating" local authorities might have to be restarted every four years (i.e. the term of office of self-governing authorities) as new people not familiar with a particular museum get elected. Regional governments (a newer governance tier created after the 1998 administrative reform) tend to have a broader understanding of museums' missions and goals.

In general, the role of museums in educating children and youth is well recognised, with some local governments purchasing or co-financing museum classes and workshops for pupils of local schools (e.g. in different governance level museums in Wilanów). Museums are less well-recognised as educational institutions for adults. Where this recognition does exist, it is mainly linked with support given by selfgoverning authorities for cooperation between museums and third age universities.

Information on museums is usually provided on municipal and regional websites as well as printed in local information booklets, regardless of museum governance level. As noted by non-municipal museums, however, local governments tend to promote their own cultural institutions, events and initiatives as a 
priority, usually giving them more visibility in municipal information materials (e.g. Zakopane, Wilanów). Cultural information booklets and schedules are also provided online and on paper, especially in major cities (e.g. Karnet, a bilingual magazine on cultural offers and events published in Krakow). In addition, some local governments (in particular through Culture, Promotion or Tourism units) create and implement city level or municipal level programmes promoting cultural participation (e.g. "Cool-tured person" competition programme in Zakopane) in which municipal, non-municipal and private cultural institutions participate.

Museums are not always eligible for municipal organisational or financial support for employee training if they are regional or national level institutions. If training is provided on a municipal level, it is more often for employees of municipal museums. It is also often beyond the scope of municipalities to support museums' cooperation with universities. If this does happen, it is most often within a framework of supporting the organisation of particular projects or events such as conferences or exhibitions on local history or a local cultural activity. In some cases, self-governments might support cooperation between TVET (technical and vocational training) institutions and museums. The cooperation between TVET schools and the museum in Brzeg on programmes for conservation and restoration of monuments supported by county level authorities is a good, although rare, example.

\section{Taking into consideration that a visit to a museum should be organised as an experience}

Museums in Poland are largely independent in the creation of exhibition design and narration as well as the accompanying museum offers. It is not within local governments' scope of responsibilities to influence museums' decisions on the character of museum visiting, in particular if they are not the organisers of the museum. The local or regional government might finance additional museum programmes aimed at more imaginative visits, e.g. consisting of workshops or lessons on non-standard topics. For example, the "Cultural Voucher" ("Bon Kultury") programme of Małopolska has been implemented for 6 years in 19 regional cultural institutions, including museums such as the museum in Zakopane. It provides free or reduced priced access to special workshops and learning activities. It also includes a sub-programme "We make the road to culture shorter" ("Skracamy drogę do kultury"), which offers discounts for visitor groups who travel long distances.

An interesting area of cooperation between museums and local governments is outdoor projects and exhibitions. They offer a chance to access some cultural content (e.g. information on local traditions, certain historic events or phenomena, changes in the cultural landscape) without having to visit the museum or as encouragement to visit museums, e.g. the programme of displaying Krakow Christmas Cribs $^{7}$ in different urban spaces. Local governments also create their own outdoor exhibitions drawing on a museum's specialist knowledge and archival material/collections (e.g. in Zakopane) or initiate and provide initial financial support for new ways of visiting museum grounds (e.g. The Royal Garden of Lights in Wilanów).

\section{Supporting an equilibrium between the needs of local audiences and tourists}

Local government involvement in cooperation with museums, educational institutions, tourism offices and tour operators on managing museum timetables is very limited. Decisions on opening days and hours are made by museums taking into account visitor demand, staffing and financial limitations. Local government might support occasional prolongation of visiting hours (e.g. on Museum Night) through financial support. In practice, in larger cities with broader museum offers, museums sometimes try to differentiate their opening days (e.g. to avoid the situation whereby all museums are closed on the same day). Museums which are significant tourism attractions usually lengthen their opening hours and open every day in the

\footnotetext{
7 The tradition of Krakow Christmas Crib dates back to the 19th century, it is a unique seasonal decoration that represents the Nativity of Jesus in the scenery of historical buildings of Krakow.
} 
summer tourist season, but this is linked more with museums' individual decisions than with local government support.

As already mentioned, local or regional governments sometimes create special offers for families, school groups and adults such as the Cultural Voucher in the Małopolska region or by purchase of a number of school visits for local kids (e.g. in Wilanów). In Krakow, an interesting recent initiative is the Krakow card, which is distributed free of charge to all residents of the city entitling them to significant discounts on municipal transport and visits to municipal museums. In some cases, local or regional governments encourage museum visits to less popular museums in small towns by agreeing that museum entrance is completely free of charge (e.g. in Pruszków, visits to the permanent exhibition and audio guide rentals are free; free visits are also offered at the Szydłowiec museum). This may however not be possible in all museums due to budgetary constraints. In other instances, museums can be visited free of charge one day per week (by law entrance to permanent public museum exhibitions in Poland should be free of charge once a week on a day selected by museum management).

The Historical Museum of the City of Krakow, with the consent of local authorities, clearly differentiates among museum branches. It considers those focused on catering to tourists (e.g. the Schindler's Factory and Main Square underground branches) and those museum branches with much smaller visitor numbers, which do not generate income for the museum but cater mainly to local residents as important local community reference centres (e.g. Nowa Huta, Podgórze or Zwierzyniec branches in Krakow).

\section{Action options for museums}

\section{Providing support to creativity development}

In many museums in Poland, including those included in this study, there has been a significant change in the way they communicate with their audiences and the type of offers they provide, although broader changes in museum exhibitions or more imaginative cultural programmes are often constrained by financial limitations. A growing share of museum activities concern organising imaginative museum learning activities and workshops. Many of them directly stimulate visitors' creativity in problem solving, group work or developing manual and artistic skills. Museum programmes include diverse events and offers for different age groups and visitor groups (school groups, family groups, seniors, the disabled). Visitors not only observe and learn about the history and artistic qualities of visited sites or objects from museums' collections, but also might acquire knowledge and skills on particular crafts, conservation techniques, creative writing or design (e.g. programmes in Wilanów, Pruszków, Szydłowiec, Krakow). Museums are also often involved in cooperation with creative education institutions (e.g. cultural centres, music and fine art schools), with their collections serving as important inspiration and background for teaching creative skills (e.g. traditional highlander music in Zakopane).

Museums are also opening their conservation workshops to visitors more often, showing the complexity of conservation processes but also teaching about conservation (e.g. Thesaurus Cracoviensis branch of the Krakow museum, furniture conservation courses in Wilanów). Museums also try to creatively use their immediate surroundings (green grounds, park grounds, urban space) by conducting special walks, treasure hunts or urban games. There is also growing awareness of the need for a very careful introduction of multimedia and limitations of multimedia exhibitions. Museums try to strike a balance between showing original objects and satisfying visitors' curiosity on certain details by provision of interactive multimedia panels or copies of original objects which visitors can try to wear, use, and interact with (e.g. in Szydłowiec, Pruszków).

All of the analysed museums are also active in organising creative competitions, mainly (though not exclusively) for children, but also for artists and designers as well as outdoor and indoor photography or painting sessions. Visitors' imagination and creativity are also inspired by the presence of trained 
educators, storytellers, provision of graphic materials and specialised guidebooks, audio guides and mobile applications in some museums. In one specific case (the Storyteller Museum in Konstancin Jeziorna), visits are by definition a creative experience of engaging in different story telling practices using sounds, movements, images and shapes.

Information on museum collections, buildings and objects on display is also provided online in diverse forms. Apart from provision of information on the museum and its collections on standard web pages, larger museums with sufficient staff and budgets have recently developed comprehensive information tools such as virtual museum databases and virtual archives or "vortals" linked with objects in museum collections and themes key for a given museum (e.g. Museum of Warsaw Rising, Museum in Wilanów). Smaller, specialist museums might in turn cooperate with national level institutions on more comprehensive virtual tools (e.g. cooperation of the museum in Szydłowiec with the National Institute of Music and Dance to have items from the museum collection shown and described on the national web page on folk music instruments).

Visitors' opinions are taken into account in the development of museum programmes and offer in all of the analysed museums. Development of a broad workshop offer for families and children in Wilanów is a good example of a museum responding to demand voiced by local audience following a local audience survey. Few of them, however, conduct regular audience opinion surveys. When this does occur, it is more often in larger museums, e.g. in Wilanów or Krakow, where the "Krakow Culture Consumer" project conducted audience research across several cultural institutions. More frequently, incidental conversations with visitors or online comments inspire new ideas. Electronic newsletters and social media have become important communication tools for museums, both providing potential visitors and audiences with up-todate information and getting feedback from them. The development of museum offers targeted to schools is also a good example of responsiveness to audience (e.g. conferences for teachers from the region organised in Zabrze).

\section{Expanding the role of museums in education by addressing the needs of various population groups}

As mentioned above, museums increasingly take into account school curriculum requirements and adjust their offers to fit educational programmes and requirements. They cooperate with educational institutions on all levels - from kindergartens to universities, in many cases developing a broader, long-term cooperation. School visits to museums are not a rule but rather depend on particular schools' and teachers' enthusiasm and willingness to organise school visits. They are constrained by issues such as the number of teaching hours and fulfilment of main curriculum aims. Museum visiting is thus easier to integrate in school activities on lower education levels (preschool and first elementary school classes with a more flexible teaching programme) than on higher levels, when paradoxically pupils are better prepared to absorb the knowledge provided by museums.

Museums are also important partners of increasingly popular "third age" or senior universities in Poland. Moreover, some museums would like to function to a greater extent as professional training institutions, for example in conservation and restoration skills or in the tourism sector (e.g. Wilanów, Brzeg, and Krakow). The current legal framework however does not explicitly recognise museums as educational institutions or vocational institutions, making it hard for museums to develop this sphere of activity. Lack of such recognition also means that museums face difficulties in accessing public funding for educational and professional training or in issuing diplomas, unless they partner with education and training institutions (e.g. co-organisation of programmes with vocational schools or with universities, such as the postgraduate programme of "Museology Studies" at Wilanów or the "Cracoviana" programme in Krakow).

In general, museums encourage their staff to develop their skills and relevant knowledge to create more imaginative and interesting museum offers to reach various audiences. They do so through conferences, study visits, and courses, both conducted in house and externally, benefiting from offers of larger 
institutions or specialised bodies such as the National Institute for Museums and Public Collections, universities or the International Cultural Centre in Krakow. For example, the Wilanów museum is the initiator and main managing body of the Polish edition of the ECHOCAST (European Cultural Heritage Organizations Customer Awareness Staff Training). However, financial limitations as well as small staff numbers might limit engagement of employees of smaller institutions in training programmes.

\section{Engaging diverse audiences}

Improving the accessibility of museums is an important issue in Poland. Whenever investments and renovations are conducted in museums, if possible (e.g. taking into account monument conservation constraints), physical accessibility of museum buildings and interiors is improved (e.g. for the disabled, people with small children, seniors). Development of audio description and object copies also increases the accessibility of collections and narrations to people with vision disability. These services can be made accessible to the prospective beneficiaries of the national Accessibility Plus Programme. In this context, a unique initiative is the programme of the Małopolska regional government entitled "Małopolska. Sensitive Culture" started in 2016 aiming at making all regional cultural institutions (cultural centres, museums and theatres) more accessible and welcoming to the disabled thanks to training for cultural institutions' employees and the development of special offers for the disabled with eyesight and hearing dysfunctions (including a special certification programme).

All of the analysed museums use their main collection theme very imaginatively to develop diverse exhibitions, programmes and activities, including workshops. Examples include imaginative use of references to ancient times in Pruszków, to the times of King John III, 17th and 18th century in Wilanów, mining heritage in Zabrze, and folk music and music instruments in Szydłowiec. In most cases, each of the museums also organises annual multidisciplinary festivals inspired by the main collection theme.

Reaching out to persons who do not traditionally go to museums is done, among other approaches, through outdoor presentations and exhibitions in urban spaces as well as initiatives such as Museum Days, Festivals, or Museum Nights. Museums use opportunities to provide reduce priced or free entrance to selected visitor groups, though particular discount programmes might only be available to a specific museum type (e.g. state museums, museums in a given region). In state-owned or co-run institutions (i.e. national institutions) these might be the "Accessible Culture" programme, "Culture for 1 zloty programme" or the "Free November in Royal Residences Programme". In most cases, museums also participate in the "Large Family Card" programme. Museum visiting and cultural participation might also be stimulated through museum programmes involving several museum institutions. For example, the Warsaw Uprising Museum is the initiator and coordinator of the "One, two, three, a Varsovian should you be" interinstitutional urban game in which numerous cultural institutions from Warsaw and the surrounding area contribute to a joint educational program.

Opportunities to engage with diverse audiences are also found through the development of additional nonmuseum services in museums. They include playgrounds, cafes and restaurants or conference and meeting rooms - museum functions usually foreseen in all construction and renovation programmes (e.g. currently in Wilanów, Zakopane, Museum of Warsaw Uprising and Krakow). In addition, a trend of growing importance is the provision of spaces in Polish museums for special interest groups, creative groups and associations (e.g. theatre groups, music groups) as well as local associations (e.g. Podgórze branch of Krakow museums, Wilanów). 


\section{Opportunities for future action}

Based on the case study process and self-assessment framework, some possible opportunities for future action could include the following:

\section{Defining the role of museums in life-long and adult learning as well as enhancing cooperation with schools}

\section{Opportunities for Museum Law / Parliament Commission for Culture, Ministry of National} Education

- Recognise the possible role of museums as centres for life-long learning, postgraduate, vocational and artisanal education (especially related to rare and traditional crafts). Consider giving them legal possibilities to organise educational programmes, issue accredited certificates and diplomas, as well as tap into direct public financial support for such activities from unemployment, life-long learning and educational budgets. Consider providing incentives for cooperation between museums and TVET organisations.

- Enable more effective and frequent use of museums as education sites integrated with school programmes, for example by introducing additional hours for museum visiting in obligatory school curricula, providing additional funding for such teaching hours and transport/travel to museums, or introducing a national museum visiting voucher programme that can be used in local and non-local museums in a given school year, without privileging national level institutions only.

- Treat museums as cultural hubs where the cultural economy can be developed. Museums are places to develop knowledge, sensitivity, local traditions and global contacts in an inspiring milieu, as well as stimulate emotion focusing on individual and local heritage.

\section{Enhancing the use of new technologies for audience engagement and experience}

\section{Opportunities for museums as well as national and regional governments}

- Develop information tools such as virtual museums, museum databases and archives or portals linked with objects in museum collections and themes. Update existing databases ${ }^{8}$ to develop educational, tourism or social networks linking museums and other institutions (schools, tourist centres, hospitals).

- Particularly for smaller/specialised museums, cooperate with national and regional level institutions to create more comprehensive virtual tools to make learning more inspiring and engaging.

\footnotetext{
${ }^{8}$ For example the Museum of King John III's Palace "Passage of Knowledge"; the "Polish folk musical instruments" web-page (http://ludowe.instrumenty.edu.pl/en); "Małopolska's Virtual Museums" - a special portal for presentations of museums and their collections in the Małopolska region, http://muzea.malopolska.pl/en/.
} 


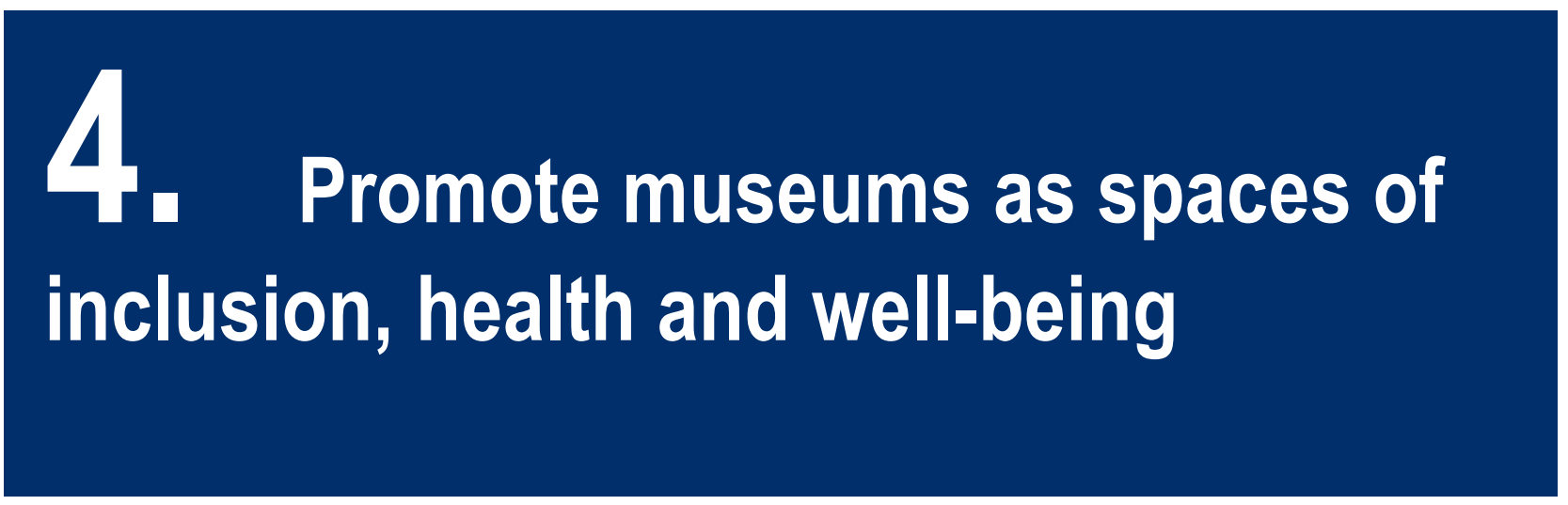

Traditionally, local governments do not consider museums as direct actors in social development beyond their educational role. However, museums increasingly contribute to individual and collective well-being. Their potential contributions, for example, to health are particularly important in the context of ageing populations. Other initiatives relating to school drop-outs or the rehabilitation of ex-offenders and the improvement of self-confidence are also significant, but are sometimes neglected since their effects are difficult to evaluate and are only evident in the long term.

Local governments could consider museums as resources for both building social capital as well as promoting social welfare and support the links with social institutions that intervene at the local level. In turn, museums need to build their internal capacities to be more pro-active in this field. Potential outcomes relate to:

- Changing people's perception about their needs and problems and making them more proactive in improving their own lives.

- Raising people's well-being with special consideration for marginalised groups.

- Giving people more self-confidence, upgrading their capacities and improving employability skills.

- Improving social cohesion.

\section{Policy options for local governments}

\section{Recognising the role of museums in social welfare}

This area is recognised by both local and regional governments and by museums as potentially important, but is currently not actively pursued by museums or subnational governments. Subnational governments acknowledge that cultural institutions can play an important role in terms of social inclusion, well-being and health, but do not undertake any specific activities to support museums' involvement in such issues. Museums are rarely explicitly recognised in municipal or regional development strategies and social programmes as institutions which could contribute to social inclusion.

To some extent, this is linked with the fact that specialized municipal, county and regional institutions are already charged with working in these domains. There are regional and county level employment offices, health and social care institutions at the municipal and regional level, as well as prison and detention systems managed at the supra-local level. Joint work between these institutions and museums is thus usually individual initiatives of particular institutions and their employees and dependent on physical proximity to particular museum institutions (e.g. health centres, social homes and prisons who usually cooperate with museums nearest to them).

There are no special programmes linked with providing museums with information on socio-economic and health related issues in a given area. Sharing of costs between museums and other institutions linked with 
social care and social inclusion cannot in practice be supported by local governments as spending of museums is a part of a different envelope of the public budget than spending on social care, in addition to difficulties of supporting non-municipal institutions in the case of museums managed at the regional or state level.

Museums, in turn, are increasingly involved in improving accessibility (both in terms of physical accessibility and narration for certain visitor groups) and developing programmes dedicated to visitors with disabilities and other selected groups at risk of social exclusion. However, such initiatives are not specifically supported by any public authority, but rather depend on the individual initiatives of museum employees and museum management. Such activities and programmes are also usually much more resource consuming (e.g. demand much more employee time and effort in relation to number of visitors, might create additional costs per visitor). As museum evaluation systems tend to focus on basic indicators linked with "efficiency" in attracting visitors, museums are not offered any specific resources by state authorities or their organising (management) bodies (with a few exceptions, e.g. regional museum institutions in Małopolska). They face no particular incentives to develop such programmes, apart from personal satisfaction and positive publicity.

\section{Supporting museums in addressing unemployment}

Practically all Polish museums cooperate with county and regional level employment offices. Museums provide employment offices with information on staffing needs, and employment offices select and propose potential trainees to museums. Such internships are mainly financed from the employment offices' budget and are much appreciated by museums, since they provide them with additional staffing at no additional cost. A certain share of trainees eventually find regular employment in the museums where they had internships. Such cooperation also takes place at the city level in the case of cities with county rights such as Krakow and Warsaw. In the Małopolska region, one such example is an initiative of the regional authorities and regional employment office to implement training in the museum and conservation field for the unemployed (the "Conservator" programme). Most museums are also important partners of educational institutions (especially universities) in terms of student traineeships.

A challenge already mentioned is the lack of regulations that would enable museums to function to a greater extent (other than as cooperating partners) as centres of vocational training, especially related to traditional and rare crafts and conservation skills.

\section{Supporting the involvement of museums in addressing well-being and health}

Museums receive no specific support from any public authority in Poland in relation to well-being and health. As already mentioned, in practice, cooperation between museums with health care and social aid institutions happens mainly thanks to personal interest and connections between museum staff and staff of social care homes or hospitals. There is also no special encouragement offered to museums to create exhibitions and other museum activities promoting health issues or healthy lifestyles.

Some municipal authorities (or in general museum supervisory bodies depending on the level of museum ownership) involve museums in environmental protection campaigns and schemes. For example, they create municipal employee mobility programmes (e.g. encouraging the use of public transport to get to work) and more sustainable heating and lightning or energy saving initiatives.

\section{Supporting museums in working with incarcerated populations}

There are no special public programmes that support cooperation between museums and prisons. Joint programmes take place upon the initiative of individual penitentiary institutions and museums. Making parts of museum collections available outside museum walls (e.g. displaying them in prisons) is not up to the 
decision of local or regional authorities but particular museums and contingent upon protection and conservation requirements (in practice happens very rarely).

\section{Action options for museums}

\section{Promoting self-confidence and skills for marginalised populations}

Museums in Poland often exchange information and cooperate with county and regional level employment offices, mainly on employee placement and internship programmes for individual unemployed persons. As already mentioned, according to Polish law, museums are not a place of structured vocational education. Occasionally, depending on the museum profile, museums might serve as spaces in which some classes of vocational training schools or university courses are conducted (e.g. mining classes in Zabrze). Some of the museums in the study cooperate with vocational training (e.g. Brzeg), and two of them offer postgraduate programmes in partnership with universities (e.g. Wilanów and Krakow). The Museum of King John III's palace in Wilanów plans to develop this dimension of museum activities to a much greater extent in the future as a training centre for rare and traditional crafts. This is, however, dependent on finding appropriate legal solutions for conducting such educational programmes and funding for the adaptation of some of the museum grounds and buildings.

\section{Addressing health and social inclusion through the use of their collections or the development of experiences}

As already mentioned, museums are increasingly involved in initiatives to support health and social inclusion, although their activities in this area are modest. Currently, most museums in Poland cooperate with some health institutions and create programmes for visitors with special needs. However, with a few exceptions, such initiatives are not particularly encouraged by any public authority, making them dependent on the personal initiative of museum employees or management with special needs schools and health institution employees.

The only area of broader explicit public support for such issues is physical accessibility of museum buildings and sites. For example, some investments linked with physical accessibility in museum buildings are supported by the State Fund for the Rehabilitation for the Disabled - PFRON, Accessible Culture and Accessibility Plus programmes. Practically all museum investment programmes conducted in Poland now include the goal of improving physical accessibility for persons with physical disabilities.

Some museums also make their exhibitions more accessible to disabled visitors. They do so through tactile exhibitions, maps, models and copies of objects, information boards in Braille language, and audio description, or are involved in programmes to interpret heritage sites in urban spaces for people with disabilities (e.g. in Krakow). Non-state owned (municipal, county, regional and private) museums can apply for funding for exhibition organisation and adjustment or special museum programmes within the framework of the Minister of Culture and National Heritage Programme "Supporting museum activities". However, programmes linked with improving the accessibility of an exhibition to the disabled compete with many other projects with a different focus. Special regional programmes (e.g. in Małopolska region) also support exhibition adjustments to special visitor needs.

Overall, there has been a significant increase in the number and variety of museum offers (especially classes and workshops) prepared especially for and adjusted for various groups of people with disabilities, as evident in almost all of the analysed museums. This happens thanks to the on-going training of museum employees on such issues (e.g. trainings with respect to needs of visitors with autism or visitors with visual disability, trainings in sign language). Such trainings are often done in cooperation with or by specialised institutions, mainly non-governmental, but sometimes also municipal organisations and special needs 
schools (e.g. cooperation of Wilanów, Krakow and Szydłowiec museums with such organisations, the cooperation between Wilanów museum and the Alzheimer Centre in Warsaw is another good example). In some cases, special museum programmes that a given museum is well known for are explicitly adjusted for special visitor needs (e.g. Christmas Crib workshops for the blind in Krakow; therapeutic volunteering in Warsaw Rising Museum).

In terms of economic accessibility to museums for disadvantaged social groups and the disabled, museums often offer free entrance and tours. They do so for groups from social care homes, orphanages, psychiatric hospitals, and alcohol and drug rehabilitation institutions, making use of available support programmes (e.g. "Accessible Culture" in the case of national cultural institutions). Museums also conduct lectures and workshops for patients of social care homes (e.g. Wilanów, Krakow), either in the museum or at particular institutions.

Museum activities addressed to or involving senior citizens and cooperation with senior citizens organisations are increasingly popular, particularly in partnership with universities of the third age. Museums and museum branches might also respond to needs of the particular local populations by creating special programmes for children and families from disadvantaged neighbourhoods in danger of social exclusion (e.g. Krakow, Zabrze).

Activities addressed to or involving specific ethnic and religious groups in danger of exclusion are, for now, marginal in Polish museums, mainly due to the largely mono-ethnic character of Polish society after World War II. However, such activities are increasingly recognised as a potential important area for museums (e.g. the need to create special programmes for the growing Ukrainian minority).

Museum activities linked with social inclusion are typically contingent on effective cooperation with nongovernmental organisations focused on specific issues such as particular disabilities, ethnic groups or age groups. It is usually through such organisations that public funds supporting social integration and health are channelled, as museums do not have direct access to such funding on their own. Such programmes with relevant public and non-governmental institutions are often organised across departments as a cross unit and multidisciplinary effort.

\section{Contributing to well-being through education and awareness raising}

Museums in Poland are rarely involved in preparing and showing exhibitions on health and environmental issues, unless their profile is directly linked with them (e.g. museums of medical schools, nature and natural history museums). However, the museums included in this study are increasingly involved in environmental protection and education. This occurs often in response to local environmental threats (e.g. ongoing programmes in Wilanów, annual Earth Week in Zabrze) as well as the result of fruitful partnerships with environmental protection bodies (e.g. partnership between Tatra Museum in Zakopane and Tatra National Park), at times building on the specificity of the museum (e.g. metallurgy museum in Pruszków). In the case of particular museums (e.g. Wilanów), engaging in environmental education is linked with the revaluation of the meaning and importance of the park and garden grounds managed by the museum and the interest of local museum goers in these issues.

Museums may also undertake activities related to the promotion of healthy lifestyles. They encourage the use of public transport and biking instead of driving, following a healthy diet, using locally produced foodstuffs, walking in green leisure grounds or the need for relaxation in peace and quiet (e.g. Krakow, Warsaw).

\section{Contributing to the rehabilitation of prisoners and ex-offenders}

Factors influencing cooperation between museums and penitentiary institutions and criminal justice actors include the relative proximity of relevant institutions (e.g. in the same city or county) as well as the museum profile. Museums focused on sensitive themes of war or genocide in general seem to be more involved in 
partnerships with prison institutions (e.g. Warsaw Rising Museum, branches of the Historical Museum of the City of Krakow focused on World War II).

Cooperation between Polish museums and prisons takes three main forms. They include: i) visits for small groups of convicts and persons on probation organised in museums; ii) museum lectures, lessons and film screenings conducted in prisons by museum employees (e.g. Warsaw Rising Museum cooperation with the Warsaw-Służewiec Detention Center); and iii) broader forms of cooperation. For example, convicts can help in cleaning, maintenance work in museum buildings or in museum grounds and gardens (e.g. Wilanów, Brzeg, Zabrze). They can also get involved in charitable programmes together with museums (e.g. the "Octopus" toys programme for children in hospitals with participation of the museum in Brzeg and the local prison).

Museum activities focused on education and the engagement of children and youth from disadvantaged neighbourhoods can also be seen as engagement in preventative activities (e.g. museum programmes conducted in the Nowa Huta branch of Krakow museum).

\section{Working in partnership with corresponding social institutions}

Partnerships with social institutions in charge of inclusion, well-being and crime prevention issues happen mainly on an ad hoc basis, based on individual, personal links and not as an outcome of special coordinated, systematic efforts. They usually depend on both sides contributing resources (employee time, provision of space) and sharing costs of conducting such programmes. In the process, knowledge and experience is shared and gained by employees on both sides. However, museum involvement in such cooperation might be constrained by the fact that they can rarely be eligible for funding from social care or social welfare budgets.

\section{Adapting internal management and governance frameworks to support museum engagement in such activities}

In general, museum managers and employees in Poland are open to ideas and suggestions of employee training and employee involvement in cooperation with social aid, health and penitentiary institutions or other relevant bodies. Museum structures are either small enough or flexible enough to accommodate such interdisciplinary initiatives (e.g. if needed multidisciplinary task groups can be created for specific projects).

Despite the fact that museums would like to implement more social inclusion programmes and activities, as in the case of employment schemes, for now museum institutions are usually not understood (by law and management bodies of public support programmes) as institutions which might get involved in providing social care and social inclusion, which means they are not able to access many sources of relevant funding.

\section{Opportunities for future action}

Based on the case study process and self-assessment framework, some possible opportunities for future action could include the following:

\section{Making museums more accessible to persons with special needs}

Museums in Poland have worked towards the physical accessibility of museum buildings and sites. This includes some investments linked with physical accessibility in museum buildings supported by State Fund for the Rehabilitation for the Disabled - PFRON. Under "Activity 25: Culture without barriers" in the action plan for the Accessibility Plus programme, the need to modernise the infrastructure and innovate in terms of more accessible cultural offerings for disadvantaged groups of society has been recognised. Museums 
too can play an important role in contributing to the realisation of the goals under the Accessibility Plus programme.

\section{Opportunities for Ministry of Health; Ministry of Family, Labour and Social Policy; National Health Fund; Ministry of Culture and National Heritage; National Institute for Museums and Public Collections}

- Continue support for improving the physical accessibility of museums through the State Fund for the Rehabilitation for the Disabled - PFRON to make buildings and their external spaces more accessible for elderly persons and people with special needs.

- Extend support to smaller museums for the digitalisation of their collections; develop information standards that are applied on websites, leaflets and other promotional materials; and create audio descriptions and copies of objects.

- Consider special public support that provides incentives for museums to conduct programmes (e.g. workshops, classes, visits) for visitors with special needs. Continue and further develop existing programmes such as Accessible Culture and Accessibility Plus.

\section{Opportunities for museums}

- Curate exhibitions and engage with other museums or specialised agencies to create activities/programmes that advocate for the resolution of social issues, promote healthy life styles, mental well-being and sustainability, and increase environmental awareness.

- Promote continuous training of museum employees to provide services to all visitors while taking into consideration the needs of specific groups of visitors (e.g. people with autism, visual disability). Such trainings can be conducted in cooperation with or by specialised institutions (e.g. NGOs, municipal organisations, special needs schools).

\section{Enabling museums to promote social inclusion for disadvantaged groups}

\section{Opportunities for local governments}

- Support museums, especially museums with fewer resources, to play a role in the social inclusion of disadvantaged groups. This is not restricted to the curation of exhibitions that highlight the challenges these groups face, but also activities, workshops and events that involve them or even create possibilities for employment.

- Use a cross-sectoral approach that involves various relevant departments within the local government (cultural, social inclusion, employment, health, etc.) and other stakeholders (public employment services, health institutions, schools, etc.) in the inception, design and implementation of programmes.

- Use participatory processes that engage different community groups and other stakeholders in problem definition, programme design, implementation and evaluation.

\section{Partnering for crime prevention and re-integration of ex-offenders}

\section{Opportunities for museums}

- Review and promote the experiences of specific museums to support and broaden cooperation with penitentiary institutions.

- Promote museum activities focused on education and the engagement of children and youth from disadvantaged neighbourhoods so that museums engage in prevention activities.

\section{Opportunities for local governments}

- Consider the creation of special public programmes that support and encourage cooperation between museums and prisons.

- Promote existing experiences and good practices in this sphere. 


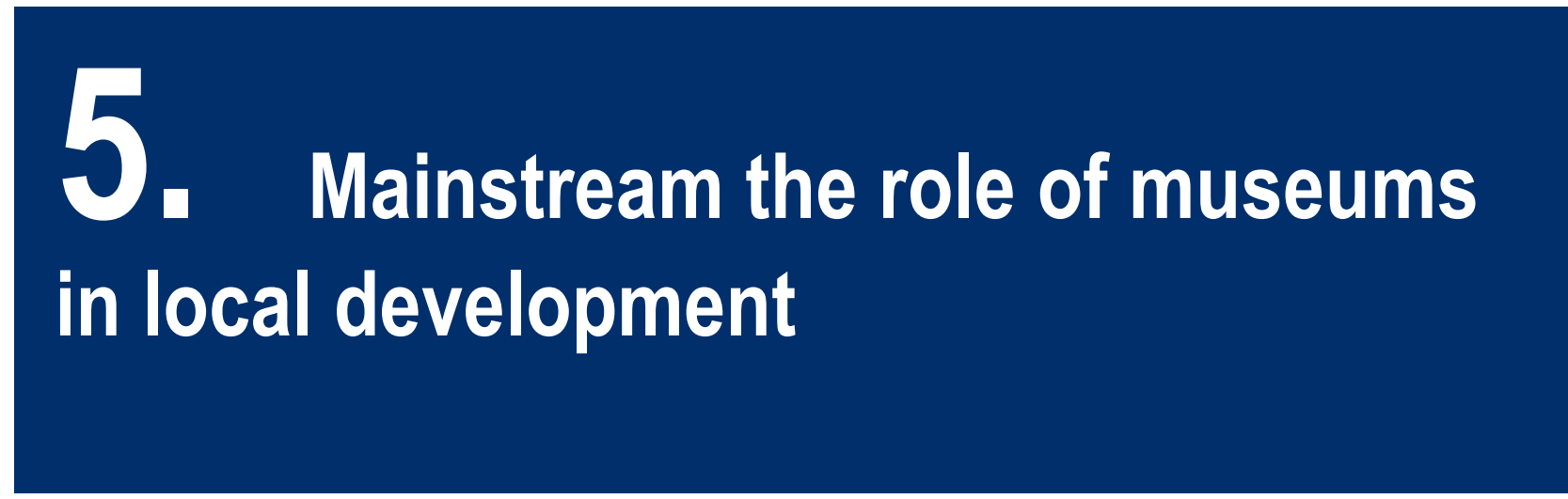

Beyond the specific areas where local governments and museums can partner to maximise the impact of museums on local development, the overall governance of the museum-local government partnership can impede or facilitate this impact. The structure of the partnership will change according to both the size of the local government and the legal framework connecting museums and local governments. Regardless of these specifics, however, the following principles generally underlie such a partnership:

- Museums can contribute to local development as both drivers and enablers. As knowledge hubs, they can design and deliver new services that create more inclusive and sustainable development.

- Local governments can mainstream the role of culture as a lever of local development and mobilise resources - regulatory, financial, land and human - that enable museums to realise their local development potential.

Mainstreaming museums in local development requires recognition of their potential for creative development and social transformation. New museum management frameworks, which account for local development issues and perspectives, are also needed.

\section{Policy options for local governments}

\section{Recognising the potential of museums for local development}

Local governments recognise the potential of museums for local development mainly through their inclusion in local and regional strategic documents. They do so either in sections on development conditions and amenities in the strategies or specific projects planned, particularly those linked with museum infrastructure (e.g. in the case of municipal museum inclusion in local development strategies, cultural development strategies or urban regeneration strategies).

The preservation, conservation and research of collections are core activities of museums. The physical and intellectual accessibility of a collection will influence the potential contribution of any museum to local development. Local governments can support the scientific needs of museums and mobilise specialised human and technical resources, provide specific spaces for storing and studying objects or carrying out specific technical tasks. They can also support or pool the conservation or other services of different local museums.

In Poland, there are no specific local government programmes linked with providing support to museums with respect to their scientific needs other than recognition of certain physical requirements for storage, conservation and the study of museum collections (humidity levels, heating, security) in plans for the construction or adaptation of municipal buildings housing museums.

Pooling conservation services across local museums is hindered by the fact that different governance levels manage different museums (though this problem might be overcome through special agreements). 
In practice, this is done without the involvement of local or regional governments through bilateral cooperation between particular museums (e.g. making use of a partner's conservation workshop for a particular type of objects such as leather, paper or metal or commissioning specific conservation tasks with employees of a different museum).

Running in-house conservation workshops is costly and only the biggest institutions can afford multidisciplinary conservation workshops. There has been an initiative to create a large, joint conservation workshop centre for all museums in Krakow (national, regional and municipal) as an inter-museum project led by the Historical Museum of the City of Krakow and the National Museum. This project has stalled, however, among other reasons due to the lack of sufficient encouragement, support and cooperation from different level public authorities. As a result, new conservation workshops have recently been developed by the Historical Museum of the City of Krakow on its own (Thesaurus Cracoviensis branch).

\section{Providing a long-term perspective to the relationship between local government and museums}

A traditional difficulty faced by museums in many countries is that their relationship with local governments is typically designed on an annual basis, due to fiscal principles. However, a longer time frame is needed to produce meaningful impacts on local development. Accordingly, it is more effective to define mutual commitments for the long term, allowing stability to build a solid foundation for growth. Commitments should also be clearly defined so that expected contributions from local government to the operation of the museum and of the museum to local development are clear and are expressed in evaluation criteria which makes sense to all parties. Finally, they should not be isolated to the culture portfolio of local governments, but rather be integrated across its operations (e.g. employment, social welfare, sustainability).

As previously discussed, museums in Poland are usually recognised as cultural amenities or as a tourist attraction, and are included in local and regional development strategies as such. Recently, they have also been increasingly recognised as a part of the creative sector, especially in metropolitan cities and at the regional level, and/or as institutions potentially useful in the development of social capital. This recognition, however, rarely translates into museums being included as important actors in broader debates on local development other than inviting their employees to roundtables and discussions on cultural development strategies. Deeper engagement is more evident when the profile of the museum is in line with general local and regional strategies of development (e.g. Museum in Zabrze in line with the strategies of Zabrze as the city of industrial tourism and the idea of Silesia as the region of industrial heritage tourism).

In general, more intensive cooperation, deeper awareness and broader expectations of museum involvement in local development is more prominent at the regional level. Indeed regional authorities usually supervise several cultural institutions of the same type and might elaborate broader general strategies with respect to them.

Museums are not offered any special incentive by local or regional authorities to be active beyond the cultural field. The "Conservator" programme for the unemployed implemented in the Małopolska region is one of the few exceptions.

Museums are evaluated by their main organising, managing and financing bodies. Therefore, local governments usually have no direct influence on the indicators used, except for municipal museums. Indirectly, however, municipal authorities can be involved in evaluations to some extent through their role in museum advisory boards. In Poland, these boards typically include both local and non-local stakeholders: representatives of managing (organising) bodies, the academic and scientific community, the non-governmental sector and representatives of the local government. By participating in meetings of the advisory board, local authorities (e.g. mayors or vice-mayors, directors of municipal departments of culture) learn about museum activities, the infrastructure and financial situation of a given museum, and its evaluation. 


\section{Encouraging museums and other stakeholders to pool resources}

Sharing of resources between museums and other (public and private) stakeholders is not usually formally encouraged by municipal or regional authorities. In practice, it does happen rather frequently (e.g. in terms of using equipment needed during outdoor events, organisation of concerts and meetings, providing space), especially between museums and nearby local institutions such as cultural centres or schools. This is typically done on an ad hoc basis, building on personal relationships between employees of particular institutions.

Both local and regional government levels acknowledge that sharing of resources, in particular sharing of resources between different institutions (museum and non-museum institutions), especially of the same governance level, should be encouraged. Often, however, it is difficult in practice due to geographic distance (e.g. regional institutions spread across a region) or legal limitations.

Sharing of resources is more common between different municipal units and municipal museums than non-locally managed museums (e.g. regional or national). Similarly, the local government might make its training system available for staff of municipally-managed museums. In addition, in the case of large municipal museums such as the one in Krakow, local authorities avoid creating new institutions and rather create new museum units (e.g. branches in specific neighbourhoods) within existing organisational and administrative structures. The local government in larger cities (e.g. Krakow, Warsaw) might also run its own network of tourism and cultural information centres (or information points) in which information on the museum offer is provided (i.e. promotion of all museums regardless of their organisational set up channelled through the general municipal budget on promotion).

The local self-government in Warsaw has introduced the "Cultural Cooperative" platform for exchanging and sharing resources between various, in particular municipal, cultural institutions. It is organised as an online portal where institutions report what resources they can share and on what basis. Borrowing (e.g. of equipment) is by definition free of charge if it serves local cultural and social initiatives and is open to Warsaw institutions and residents. Another example is a joint audience research programme "Krakow cultural consumer" supported by local and regional governments. Through this programme, several cultural institutions managed at the local, regional and national level (museums, an opera, a philharmonic hall) take part in joint research, instead of each of them doing an individual opinion survey of their own visitors.

\section{Ensuring local financial and revenue regulations are well-designed}

Despite the general recognition of the contribution of museums to attracting tourism in a given area or their impact on residential attractiveness of some districts, to date there have been no concrete motions undertaken by any governance level to measure such impacts or introduce local financial and revenue regulations that would incentivise museums financially for producing such beneficial externalities.

In Poland, any revenues generated by museums on their own (own earnings on provision of goods and services) are usually by definition treated as an additional part of their budgets to be reinvested in statutory museum activities. On the whole, own earnings represent a small share of the total budget of Polish museums (apart from a very few, exceptional cases). Only in rare cases do particular museum branches bring enough income to be almost self-sustaining (e.g. in the case of Krakow major tourism attractions such as Schindler's Factory versus local district museum branches attracting more local audiences). Similarly, there are some museum activities which do bring income (e.g. rental of spaces), but this income offsets financial costs of conducting other cultural and social activities. Currently, public financial contributions are not adjusted for a museum's own earnings, though it is worth considering whether the introduction of a certain legal safety mechanism could ensure that museums are not punished financially for increasing their earnings directly.

Following the redefinition and introduction of a new law on tourism taxes levied by local authorities, the possibility of museums sharing in this revenue could be explored. In places where tourism is mainly 
motivated by monuments and museums, a set share of such tax could be allocated to monument conservation and museums. Such a solution would, of course, require the development of efficient and transparent income sharing mechanisms.

Although there are no official regulations on this matter, local governments are usually willing to support municipal museums with additional funds if matching funds are needed to participate in EU co-funded projects, incentivising museums to pursue this type of external funding. Similarly, regional governments and regional museums may count on additional organisational and financial support (e.g. additional grants or subventions) from their managing bodies while applying for external funds and implementing projects co-funded with EU, NFM/EEA funds or Ministry of Culture and National Heritage grant schemes.

\section{Enhancing the mobilisation of volunteers}

Local and regional authorities in Poland in general do not offer any special support to promote volunteering in museums. In many cases, this is not their role as they are not official organising bodies of a given level museum (e.g. local authorities in the case of regional or national museums). Although in some cases, local authorities consider particular museums as very knowledgeable and efficient in their own efforts to attract volunteers and with no need of additional help (e.g. in Wilanów, with respect to Warsaw Rising Museum), others see the need to further develop this sphere of museum activities and are considering developing some support systems (e.g. Krakow). In the case of Małopolska regional authorities, the cultural department also sees sharing information on volunteering as an important practice linked with cooperation with museums. For many years, it has included information on a broader array of museum activities in reporting requirements to learn about and encourage regional museums to broaden their social impact.

\section{Action options for museums}

\section{Clearly articulating the museum's role in local development and operationalising it in key documents and processes}

As stated above, museums are willing to be actively involved in the development and implementation of local, regional and/or national economic and social strategies. Some of them, especially if they are closely linked with local authorities, are also more actively engage in the development of such strategies. This involvement, however, can be constrained by limitations linked with staffing, budgets and inclusion in relevant planning and strategic bodies. Museums are not by definition obligatory participants in the development of local or regional strategies. They are therefore not always invited to participate in discussions on local development, and if invited they are not always provided with sufficient background information or their opinions and recommendations are not always taken into account. Inclusion or exclusion of museums in local development discourse is therefore largely voluntary and depends on the strength and character of the social networks museum management is able to foster, rather than on statutory requirements.

Nonetheless, all of the museums in the study, regardless of their size and focus, have a strong presence in their local communities. They cooperate with various local partners (schools and other educational institutions, artistic schools, non-governmental organisations, social care and health centres, community groups) to organise local cultural and artistic events and activities. They host and co-organise diverse events and meetings of the local, county and regional level governments as well as international study groups on certain aspects of museum impact. For example, there is a new series of conferences on the presence of museums in their socio-economic milieu initiated by Wilanów museum under the auspices of ICOM or the participation of the Krakow museum in the international working group on Museums and Creative Industries functioning within the framework of the Network of European Museum Organizations (NEMO). 
Most of the analysed museums (seven out of nine) have developed formal written development strategies. Some of them are very detailed and innovative, such as the Museum Master Plan in Wilanów as a comprehensive strategy and a spatial planning document. They consider the functioning of particular institutions not only from the point of view of fulfilling basic museum functions (collection, conservation, storage, study and dissemination) but also their role in the local socio-economic milieu. Some of them have also developed very detailed state-of-the-art systems for monitoring implementation and updating strategies, dedicating much time and effort to the issue, creating special organisational structures and dedicated staff positions (e.g. Krakow, Wilanów), or even organising specialist conferences on the issue of strategic management in museums (e.g. Krakow in 2017).

In other cases, including in smaller museums, the issue of strategy implementation is a less structured process or follows the general vision of the director or manager. Despite recent development of various postgraduate programmes in museology and heritage management, there still seems to be a need to develop a system of training and assistance, especially for smaller museums, to support staff in developing strategies and monitoring of their implementation.

\section{Maintaining preservation, conservation and research as core tasks}

Documentation in terms of collection management, inventories, protection, safety and evacuation procedures is regulated on the national level and certain requirements have to be complied with by museums, in particular institutions which are "registered museums". However, in some institutions, strategic planning, especially in terms of the development of collections to enhance their artistic and social value and the interpretation of collections in a way that brings out their unique aspects, could be improved with external assistance (e.g. special programmes on the national level). Larger institutions are in general better prepared for the challenge of collection management and to undertake innovative efforts to further develop such skills (e.g. involvement of Wilanów museum in a pan-European project (CRONACH) on preventive conservation in historic residences). Some museums also cooperate with other institutions (both in Poland and abroad) dealing with similar collections, objects or sites (e.g. industrial heritage in the case of Zabrze; city museums in the case of Krakow) and find the sharing of experiences and good practices very helpful in terms of effective management of their own collections and sites. In addition, museums try to apply innovative approaches to finding additional funding for the purchase, study, conservation, display or publishing efforts linked with collections. For example, the museum in Zakopane has innovatively crowdfunded to raise funds for a comprehensive monograph / album on its collection of the one of the most important Polish artists of the interwar period - Stanisław Ignacy Witkiewicz, nicknamed "Witkacy". Each person, organisation or institution donating money for the publication could "adopt" the painting that would appear in the publication and, after the publication came out, received its copy.

\section{Partnering with other relevant organisations to increase impact}

Partnerships with other relevant organisations can take various forms. As a starting point, organising regular exchange meetings between museum staff and various cultural, economic and social stakeholders at the local level can help break down formal boundaries. It can also help promote awareness of what a creative organisation entails and its potential contributions to local development. Such exchanges can also enhance more general exchange of information. More specifically, museums can partner with other museums located in the area, along with corresponding networks as relevant.

Museums are usually well informed of the socio-economic situation in their local area. Although they do not receive any special access to this type of data and information, their knowledge is gained more generally by working in a given location.

Only four museums in the study have clear mission statements provided on their web pages, despite the fact that a great majority of them have created strategic development documents. These strategies are 
usually considered internal documents. They are generally not explicitly shared with the public, although parts of a museum strategy might be disclosed at meetings of local stakeholders, shared in media information or official letters issued by museums, or publicised in relation to specific issues. For example, detailed information on local spatial planning issues and challenges and the museum's point of view on such issues is provided online by the Wilanów museum, in line with its Master Plan of development.

Sharing of resources and facilities across different museum departments is a process that occurs in a natural way (e.g. in larger, multi-branched museums, dedicated teams for marketing, administration, and transport services to all museum branches). One way to encourage fruitful cooperation between different units is to create interdisciplinary task groups for particular projects or events. In smaller museums, this happens naturally as all staff must be multifunctional. In larger institutions, it takes the form of task groups and research groups. Such structures are in fact encouraged in the larger museums in this study (e.g. Wilanów, Krakow). To ensure effective use of space and equipment, a museum might also create specific tools such as an online internal reservation calendar where all departments submit their requests and book spaces and equipment (e.g. Wilanów). In larger museums (e.g. Krakow) internal cost saving measures linked with sharing resources and organisational solutions may also include central accounting, public procurement and technical (exhibition set up) services. In some cases, outsourcing of some services is also an option used by museums to optimise their employment structure and costs (e.g. security, cleaning, conservation or servicing of multimedia).

Sharing of resources is often done while implementing joint projects with other institutions whereby both (or more) partners contribute. For example, a museum might offer objects from the collection for display and expert knowledge to create an exhibition scenario, while its partner might offer support for conservation of objects or space for their display. The links between Tatra Museum in Zakopane and the Tatra National Park are a good example of such fruitful cooperation.

In general, all of the museums in the study offer unique exhibitions and services drawing on the specificity of their collections so there is no duplication of work with other museums. However, there are examples of duplication between museums managed on a regional or national level and the activities of municipal institutions. In addition, museums, which for various organisational and financial reasons are latecomers in terms of modern museum management, might encounter more challenges and require external assistance to creatively rethink their strategic strengths and unique aspects of their collection or buildings.

In larger cities, a controversial issue is the rationality of some specialist museum institutions broadening the thematic scope of their activities which may overlap with the offer of other municipal museums. One example is the thematic scope of activities of the Museum of Warsaw and the non-World War II related activities of the Museum of Warsaw Rising. A related concern is the rationality of continuing to run an independent specialist municipal museum institution focused on a narrow topic (e.g. Museum of Photography) instead of making it a branch of the larger municipal museum (e.g. Historical Museum of the City of Krakow). Another potential concern is having a national museum institution running a museum branch far from its main seat, though its thematic scope is aligned with the profile of another larger, multibranched museum (e.g. the Szymanowski branch of the National Museum in Krakow located in Zakopane).

\section{Giving support and recognition to volunteers who contribute to the implementation of museum objectives}

Volunteering is considered an increasingly important issue by most of the museums in the study. Relationships with volunteers are built thanks to long-term local links, especially through educational and cultural activities involving children and youth or seniors (e.g. Pruszków, Krakow, Warsaw Uprising, and Wilanów). The importance of volunteering and the new attitudes to it that museum managers and staff are taking (i.e. volunteering not only as a way to bolster staffing resources but also as a way to build stronger links with the local communities) is reflected in the fact that larger museums have established special volunteer units or centres and consider space needed for volunteer activities while planning investment 
programmes. They also offer specific incentives (e.g. possibility of free of charge continued access to museum grounds, special events and meetings) to volunteers.

A growing number of persons from older age groups have started to volunteer, especially in larger cities, provided that the given museum offers them clear information on the possibility and variety of potential tasks (e.g. gardening, education, reconstruction in Wilanów). Volunteering might be constrained by the nature of the local social milieu - especially in smaller towns, with a smaller pool of potential volunteers. There may also be no traditions of volunteering of older generations, a smaller number of schools, or a lack of academic institutions (e.g. Szydłowiec). There may also be organisational limitations, such as space, knowledge of museum employees on the formal aspects of volunteering, or insufficient staff numbers to supervise volunteers and design tasks for them.

Sometimes instead of formal volunteering agreements, museums draw on voluntary help within the framework of cooperation with educational institutions such as schools (e.g. Brzeg). A new, but for now marginal, development is the emergence of corporate or institutional volunteer programmes, including city hall employees volunteering in public institutions in the municipality (e.g. Warsaw). This type of volunteering might be regarded as especially important as it offers a chance for municipal employees to get first-hand knowledge and insight into the functioning of museums, and learn about the specificity, needs and potential of a particular museum.

Overall, there is an inequality of expectations regarding the role and level of interest in cooperation between museums with local and regional governments. In most cases, therefore, the local and regional governments might rate their cooperation with museums and the role in stimulating museum contributions to local development higher than this cooperation is assessed from the perspective of museums, in particular when the municipal governance level is not the museum's organising body.

\section{Opportunities for future action}

Based on the case study process and self-assessment framework, some possible opportunities for future action could include the following:

\section{Strengthening evaluation and knowledge-sharing practices}

\section{Opportunities for the National Institute for Museums and Public Collections}

- Conduct an independent study on the effects of merging cultural services under an umbrella of one larger municipal institution (e.g. the Municipal Cultural Centre consisting of a library, a cultural centre and a museum) implemented in the last two decades by several municipalities in Poland.

\section{Opportunities for museums}

- Exchange experiences on evaluation, monitoring and strategy development with other museums.

- Monitor and address instances of overlapping of museum and local government activities in a given area.

- Exchange experiences and good practices on how museums can be involved in local development.

- Organise courses and professional seminars for museum staff on museum economics and socioeconomic issues linked with the functioning of museums. 


\section{Raising awareness about the potential role that museums can play in fostering local development}

\section{Opportunities for museums as well as local, regional and national government}

- Develop a special education campaign (short conferences, longer courses, publications and leaflets) aimed at all levels of government (from central to local) to increase awareness of the ways that museums can contribute to local development.

- Raise awareness of the diverse links between museums and urban planning and design among local authorities and of the variety of potential indicators and qualitative information relevant to assessing the functioning of museums.

- Promote good practices and innovative solutions developed by museums and territorial governments (e.g. by publishing guides on good practices such as the "Cultural Voucher" programme in the Małopolska region or the idea of Cultural Heritage Councils linked with leading museums in a given county or region currently implemented in Zakopane).

\section{Strengthen training for museum personnel}

\section{Opportunities for museums, the Ministry of Culture and National Heritage, and the National Institute for Museums and Public Collections}

- Create more possibilities for museum employees, especially from smaller, more peripheral museums to participate in training sessions and relevant study programmes conducted by higher education institutions and selected museums who became experts in specific fields related to the expansion of the museum role in local development.

- Raise awareness and knowledge of museum employees on the issue of intellectual property rights and their protection.

- Create and implement a nation-wide museum volunteering campaign to make the public aware of the possibilities of volunteering in museums and help museums to attract volunteers from different age groups. Complement this campaign by educating museums about the benefits of as well as legal and practical aspects associated with volunteering.

- Improve the skills of existing museum employees and enable hiring of new personnel adept in handling new tasks associated with the museum's expanding functions to create social inclusion and economic development.

- Update museum studies/museology and heritage management curriculum at higher schools and universities to reflect the expanding role of museums. 


\section{References}

Andrzejkowicz, K. and K. Figiel (eds.) (2017), Museums in 2016, National Institute for Museums and Public Collections, Warsaw, https://www.nimoz.pl/files/publications/42/Museum Statistics online.pdf.

Andrzejkowicz, K. and K. Żmijewska (eds.) (2018), Museums in 2017, https://nimoz.pl/files/publications/60/ANG NIMOZ www 150219.pdf.

Folga-Januszewska, D. (ed.) (2018), Extended museum in its milieu, Universitas.

Folga-Januszewska, D. (ed.) (2012), Polish museums, Bosz, Olszanica.

Folga-Januszewska, D. (2011), 1000 museums in Poland: a guide, Bosz, Olszanica.

Lorentz, S. (1974), Guide to museums and collections in Poland, Interpress Publishers, Warsaw.

Murzyn-Kupisz, M. (2019), "The socio-economic impact of museums and their relationships with the surrounding environment", Museums in 2018, pp. 26-73, https://nimoz.pl/files//articles/173/Museum\%20Statistics 2018 EN.pdf.

Murzyn-Kupisz, M. (2010), "Cultural policy at the regional level: a decade of experiences of new regions in Poland", Cultural Trends, Vol. 19/1-2, pp. 65-80, https://doi.org/10.1080/09548961003696070.

Murzyn-Kupisz, M. and J. Dzialek (2015), "Libraries and museums as breeding grounds of social capital and creativity: potential and challenges in the post-socialist context", Creative economies, creative communities. Rethinking place, policy and practice, pp. 145-169.

Murzyn-Kupisz, M., K. Figiel and K. Andrzejkowicz (eds.) (2017), "Socio-economic aspects of museum operations: employment, income and expenditure in museums", Museums in Poland. Reports based on data from the Museum Statistics project (2013-2016), pp. pp. 79112 , https://nimoz.pl/files/publications/40/Statystyka\%20Muzea\%20w\%20Polsce\%20Raport\%20E $\underline{\mathrm{N} \text { lekki.pdf. }}$

National Institute for Museums and Public Collections (2018), Museum Statistics in 2016 and 2017, National Institute for Museums and Public Collections, Warsaw.

National Institute for Museums and Public Collections (2017), Museum Statistics, National Institute for Museums and Public Collections, Warsaw, https://nimoz.pl/files/publications/42/Museum Statistics online.pdf. 
Neiroba, E. (2018), Dynamics in the Field of Museums: Contemporary Challenges for Polish Museologists, https://www.mdpi.com/2076-0760/7/5/77.

Nowacki, M. (2007), Museums and related institutions in Poland following political transformation, http://dx.doi.org/10.1080/09647770701628636.

Statistics Poland (2019), Culture in 2018, https://stat.gov.pl/en/topics/culture-tourismsport/culture/culture-in-2018,1,11.html.

Statistics Poland (2018), Culture in 2017, https://stat.gov.pl/en/topics/culture-tourismsport/culture/culture-in-2017,1,10.html. 